\title{
Gold (III) Derivatives in Colon Cancer Treatment
}

\author{
Agata Gurba ${ }^{1, *(\mathbb{D}}$, Przemysław Taciak ${ }^{1}$, Mariusz Sacharczuk ${ }^{1,2}$, Izabela Młynarczuk-Biały ${ }^{3}$, \\ Magdalena Bujalska-Zadrożny ${ }^{1}$ and Jakub Fichna ${ }^{4}$ (i)
}

1 Department of Pharmacodynamics, Faculty of Pharmacy, Medical University of Warsaw, 02-097 Warsaw, Poland; przemyslaw.taciak@wum.edu.pl (P.T.); mariusz.sacharczuk@wum.edu.pl (M.S.); magdalena.bujalska@wum.edu.pl (M.B.-Z.)

2 Department of Genomics, Institute of Genetics and Animal Breeding, Polish Academy of Sciences, Jastrzebiec, 05-552 Magdalenka, Poland

3 Department for Histology and Embryology, Medical University of Warsaw, Chalubinskiego 5, 02-004 Warsaw, Poland; imlynarczuk@wum.edu.pl

4 Department of Biochemistry, Faculty of Medicine, Medical University of Lodz, 92-215 Lodz, Poland; jakub.fichna@umed.lodz.pl

* Correspondence: agata.grabowska@wum.edu.pl

Citation: Gurba, A.; Taciak, P.; Sacharczuk, M.; Młynarczuk-Biały, I.; Bujalska-Zadrożny, M.; Fichna, J. Gold (III) Derivatives in Colon Cancer Treatment. Int. J. Mol. Sci. 2022, 23, 724. https://doi.org/ $10.3390 /$ ijms23020724

Academic Editors: Enikö Kallay, Andrzej Kutner and Geoffrey Brown

Received: 16 December 2021

Accepted: 4 January 2022

Published: 10 January 2022

Publisher's Note: MDPI stays neutral with regard to jurisdictional claims in published maps and institutional affiliations.

Copyright: (C) 2022 by the authors. Licensee MDPI, Basel, Switzerland. This article is an open access article distributed under the terms and conditions of the Creative Commons Attribution (CC BY) license (https:// creativecommons.org/licenses/by/ $4.0 /)$

\begin{abstract}
Cancer is one of the leading causes of morbidity and mortality worldwide. Colorectal cancer (CRC) is the third most frequently diagnosed cancer in men and the second in women. Standard patterns of antitumor therapy, including cisplatin, are ineffective due to their lack of specificity for tumor cells, development of drug resistance, and severe side effects. For this reason, new methods and strategies for CRC treatment are urgently needed. Current research includes novel platinum (Pt)- and other metal-based drugs such as gold (Au), silver (Ag), iridium (Ir), or ruthenium $(\mathrm{Ru}) . \mathrm{Au}(\mathrm{III})$ compounds are promising drug candidates for CRC treatment due to their structural similarity to $\mathrm{Pt}(\mathrm{II})$. Their advantage is their relatively good solubility in water, but their disadvantage is an unsatisfactory stability under physiological conditions. Due to these limitations, work is still underway to improve the formula of $\mathrm{Au}$ (III) complexes by combining with various types of ligands capable of stabilizing the $\mathrm{Au}(\mathrm{III})$ cation and preventing its reduction under physiological conditions. This review summarizes the achievements in the field of stable $\mathrm{Au}$ (III) complexes with potential cytotoxic activity restricted to cancer cells. Moreover, it has been shown that not nucleic acids but various protein structures such as thioredoxin reductase ( $\operatorname{Tr} x \mathrm{R})$ mediate the antitumor effects of $\mathrm{Au}$ derivatives. The state of the art of the in vivo studies so far conducted is also described.
\end{abstract}

Keywords: gold; $\mathrm{Au}(\mathrm{III})$ complex; colorectal cancer; anticancer drugs; organometallic; cancer therapy; cytotoxicity; metallodrugs

\section{Introduction}

Cancer is one of the leading causes of morbidity and mortality in the world, being responsible for approximately 9.6 million deaths in 2018 [1] and almost 10.0 million in 2020 [2]. According to global epidemiological data, colorectal cancer (CRC) is the third most frequently diagnosed cancer in men and the second in women. The worldwide burden of the disease is estimated to rise by $60 \%$ to over 2.2 million new cases and 1.1 million deaths by 2030. As reported in National Registry of Cancers, there has been a continuous increase in colon cancer incidence rate in Poland, with 4720 newly diagnosed cases [3,4].

Colon cancer develops as a result of the change of normal colonic epithelium including dysplasia and metaplasia to cancerous tumor, both polyposis and nonpolyposis, as a result of genetic alterations and the functional impact of these changes [5]. Colorectal tumors are driven by a wide range of spontaneous or induced mutations by mutagens, which is why they constitute a very heterogeneous group of cancers that are difficult to treat $[6,7]$. In the natural history of CRC development, a sequence of mutations accumulates, including antioncogene APC that becomes inactive and drives uncontrolled cell divisions. 
Further, K-Ras hyperactivity quickens cell divisions, and finally p53 becomes inactive. The accumulation of mutations in nonhereditary forms of CRC lasts about three decades [8].

It has been observed that median age at diagnosis with invasive cancer is about 70 years in developed countries [9]. The relationship between the aging and cancer is linked to the aging of lymphocytes (immunosenescence) [10] and with DNA defects that accumulate with age as well as with hormonal changes [11]. The development of CRC in a large number of cases begins decades before its detection through the adenoma-carcinoma sequence. By that time, it reaches a late stage, which complicates the treatment [12]. The risk for developing CRC is associated with personal features or habits [13] such as age [14], chronic diseases history including inflammatory bowel disease [15], Crohn's disease [16] and sedentary lifestyle, obesity [17], unhealthy nutritional habits [18], smoking and alcohol consumption [19]. Therefore, a continuous increase in the incidence of CRC in developed countries can be attributed to an increasingly aging population, unfavorable modern eating habits and an increase in risk factors such as smoking, low physical activity and obesity [20].

In the case of early diagnosis, the basic treatment is surgery, but this is already ineffective in advanced cases with metastases, which constitute about $25 \%$ of diagnoses [21,22]. The effectiveness of a standard neoadjuvant cytotoxic therapy in these patients, based on oxaliplatin and other cisplatin analogues, has been drastically reduced by the lack of specificity towards cancer cells, rapid development of drug resistance and cancer recurrence [23].

Thus, current research has been focused on developing new metallodrugs based on other nonplatinum transition metals, such as gold (Au), silver (Ag), iridium (Ir) or ruthenium $(\mathrm{Ru})$ [24]. Another approach is the substitution of a ligand and the modification of existing chemical structures that led to the synthesis of a wide range of metal-based compounds, some of which have shown improved cytotoxic and pharmacokinetic profiles [25]. Furthermore, nanoparticles, through their enhanced permeability and retention (EPR) effect, preferentially accumulate in tumors [26], which also makes them an attractive research topic. Despite an abundant literature on gold nanoparticles in experimental cancer biology, only a few of the gold-based nanodevices are currently being tested in clinical trials [27], and none of them are approved by health agencies. In recent years, the field of cytotoxicity of Au complexes has been rapidly developing, which is reflected in numerous reviews. Au(III) compounds seem to be a particularly promising and good alternative for platinum-based anticancer drugs due to their structural similarity to platinum (Pt)(II) [28]. However, most of the described compounds have an unclear mode of action and a lack of clinical relevance. That is why we are constantly looking for new and fully characterized $\mathrm{Au}(\mathrm{III})$ derivatives. In this review, we summarize the previous work and describe the most recent advances in the use of $\mathrm{Au}(\mathrm{III})$ derivatives in CRC treatment.

\subsection{Colorectal Cancer Treatment}

CRC can be divided into five stages: 0, I, II, III and IV, depending on the involvement of lymph nodes, formation of metastases and the grade of local invasion depth. The most advanced stage with the worst prognosis is stage IV. The therapeutic approach depends on the stage of the disease. Thus, tumors at stage 0 are surgically removed while patients with stage II and above (invasive cancer crossing the basement membrane) require more complex treatment methods that include surgery, chemotherapy and/or radiotherapy [12,29,30].

The standard therapy for CRC currently involves various medicines, either in combination or as single agents, such as: 5-fluorouracyl/leucovorin (5-FU/LV), capecitabine, irinotecan, oxaliplatin, bevacizumab, cetuximab, panitumumab, ziv-aflibercept, ramucirumab, regorafenib, trifluridine-tipiracil, pembrolizumab and nivolumab. The described mechanisms of action of cytostatics are varied and include interference in DNA replication and inhibition of the activities of vascular endothelial growth factor (VEGF) and epidermal growth factors (EGF) [31-34].

In surgical treatment of CRC that crosses the basement membrane, adjuvant and neoadjuvant therapy is proposed to be the gold standard. These terms (adjuvant and 
neoadjuvant) refer to the pairing of sequential steps of therapy, that is, chemotherapy followed by surgery, or surgery followed by chemotherapy, respectively.

In context of CRC therapy, the clinical prospective data on neoadjuvat therapy is limited-patients can benefit from these treatments [35], however the limitations are side effects such as neuropathy induced by oxaliplatin - that force for the invention of better and safer alternatives, such as other metallodrugs, including gold complexes [29].

The main reason for the low effectiveness of CRC treatment is the limited bioavailability and the lack of specificity towards cancer cells of conventional chemotherapeutic agents, which contributes to the destruction not only of cancerous cells but also of normal cells, and consequently leads to serious side effects. In addition, the development of drug resistance is observed [26,36-39].

In order to optimize anticancer therapy and reduce side effects, new alternative therapies in CRC are being investigated [13]. The most promising trends of research are the use of agarose tumor macrobeads [40-42], anti-inflammatory drugs [43-45], probiotics [46-48] and metal-based drugs [29,49-52].

\subsection{Metallodrugs}

Laboratories and scientific institutions around the world have researched many derivatives of metals such as $\mathrm{Pt}, \mathrm{Au}$ and other metals for the treatment of tumors. Moreover, some of them have been patented or even implemented. A well-known drug is cisplatin, whose potent anticancer effect is derived from the interaction with DNA and impaired processes of replication, transcription and translation $[53,54]$. Unfortunately, the use of cisplatin may lead to neuro- and nephron-toxicity, along with evidence of either induced or intrinsic resistance to the treatment in some tumors $[55,56]$. Thus, development of both novel Ptand other metal-based compounds is needed in order to obtain complexes with higher effectiveness, increased selectivity for tumor tissue, reduced toxicity, wider spectrum of activity, and ability to overcome tumor resistance often arising from cisplatin treatment [57].

Currently, the most abundant group of non- $\mathrm{Pt}$, metal-based anticancer preparations are those incorporating $\mathrm{Au}$. In fact, the group of reported compounds exhibiting anticancer activity based on $\mathrm{Pt}$ is less numerous than the group with same activity based on $\mathrm{Au}$. Further down, medicinal preparations based on metallic $\mathrm{Au}(\mathrm{Au}$ 0), also known asdepending on the size of particles-colloidal or nanoparticle $\mathrm{Au}$, are by far the largest group among all therapeutic Au-based compounds [39,58,59].

Metallic Au particles are insoluble in blood and plasma, but the tumor cells exhibit the ability to greater accumulation of Au particles in relation to normal cells according to the EPR effect $[60,61]$. Despite the promising results of preclinical studies, low bioavailability and very rapid excretion from the body discourage further attempts to use metallic $\mathrm{Au}$ in the clinical setting $[62,63]$. Moreover, indicated accumulation of such compounds of Au in the liver and spleen is an important side effect [64-67].

The low bioavailability of $\mathrm{Au}(0)$-based drugs has initiated research into Au complexes that are characterized by better bioavailability and solubility. During the last two decades, a large variety of $\mathrm{Au}(\mathrm{I})$ and $\mathrm{Au}(\mathrm{III})$ compounds are reported to possess relevant antiproliferative properties in vitro against selected human tumor cell lines, qualifying them as excellent candidates for further pharmacological evaluation. The unique chemical properties of the $\mathrm{Au}$ center confer very interesting and innovative pharmacological profiles to Au-based metallodrugs [68]. As previously described, $\mathrm{Au}$ (I) and $\mathrm{Au}(\mathrm{III})$ compounds are widely used in research as anticancer agents, however, most of them display limitations concerning solution stability under physiological conditions [24,25,29,69-76]. Au(III) compounds seem to be particularly promising and a good alternative for Pt-based anticancer drugs, due to their structural similarity [28]. Currently, researchers aim to develop different types of ligands able to stabilize the $\mathrm{Au}(\mathrm{III})$ cation and prevent its reduction under physiological conditions. 


\subsection{Perspectives for Gold-Based Compounds against Colorectal Cancer}

There are several properties of $\mathrm{Au}$ that make it a potential anticancer agent in CRC. Since Au compounds have been used for centuries in the treatment of rheumatoid arthritis; their well-known anti-inflammatory and immunosuppressing properties made them promising drug candidates for CRC treatment [77].

Moreover, there is evidence that not nucleic acids, as in the case of cisplatin, but some selected protein targets, for example, thioredoxin reductase (TrxR), mediate the antitumor effects of Au derivatives [29,78-80]. This is particularly important as Trx-1 expression is upregulated in several human cancers, including CRC. The Trx/TrxR redox pathway is an attractive target for the development of new anticancer drugs, as elevated Trx- 1 levels result in rapid tumor growth, inhibition of apoptosis, and reduced patient survival [81,82]. Gold complexes have multimodal mechanisms of action, and examples of them are listed below.

Direct DNA interaction - platin-derived compounds such as oxaliplatin are standard DNA-binding therapeutics applied in CRC - it was shown that some gold complexes cause DNA fragmentation rather than cross-linkage as a result of reversible and noncovalent DNA interaction [83-86].

Gold complexes can induce apoptosis by intrinsic mechanisms involving caspase 9 and 3 activation, cytochrome $C$ release, and PARP cleavage [80,87-89].

Protein kinase $\mathrm{C}(\mathrm{PKC})$ is involved in cell proliferation, differentiation, migration, and survival. Hyperactivation of PKC signaling can be observed in cancers including CRC. Some gold complexes including aurothioglucose and aurothiomalate can inhibit PKC and consequently inhibit proliferation of cancer cells [90,91].

MEK/ERK (Ras) pathway-this pathway is necessary for proper cell divisions, and if hyperactivated it drives unhampered divisions of the cancer cell, its motility, mobility and insensitivity to induction of apoptosis. Ras hyperactivation is often involved in CRC development, but all signaling elements including growth receptors and downstream kinases (Raf, MEK, ERK) might participate in cancer progression [92].

The proteasome-ubiquitin pathway (UPS) - this cellular protein destination and degradation system was shown to be a good anticancer drug target, since proteasome inhibitors are applied in cancer treatment. Tumor cells with deregulated cell divisions are more sensitive to inhibition of UPS than normal cells that can enter the cell cycle, and block and escape death by proteasome inhibition. Particular gold complexes such as the $\mathrm{Au}(\mathrm{III})$ dithiocarbamate compound turned out to inhibit proteasome activity and induce accumulation of polyubiquitin complexes, both in vitro in tumor cell lines, as well as in xenografts resected from experimental animals [83,93].

Thus, the advantage of Au complexes is their multimodal mechanism of action targeting various elements crucial for cancer progression.

\section{In Vitro Studies}

$\mathrm{Au}(\mathrm{III})$ compounds, due to their similarity to cisplatin, were among the first metal complexes tested for anticancer activity. It was initially assumed that the mechanism of action of these compounds would be the same as Pt-based drugs, and based mainly on interactions with DNA $[94,95]$. However, subsequent studies revealed that the cytostatic effect of Au derivatives is rather multifaceted, and may include some selected proteins such as TrxR or deubiquitinases [78-80,96,97]. It is also known that these proteins are overexpressed in cancer cells, and inhibition of their activity is lethal to cancer cells, although with a much lower effect on noncancerous cells. Therefore, it is believed that the systemic toxicity of Au complexes will be significantly reduced compared to conventional therapy [29]. Notwithstanding, most of them display limitations concerning solution stability under physiological conditions and are easily reduced to $\mathrm{Au}(\mathrm{I})$ or $\mathrm{Au}(0)$, thus losing their activity. However, as the following examples show, it is possible to synthesize stable, resilient-to-reduction, organogold(III) complexes, which is the main goal in this field. To 
date, according to our knowledge, inorganic $\mathrm{Au}(\mathrm{III})$ complexes have not been described as cytostatic agents in CRC.

\subsection{Organogold Derivatives}

One of the first studies of $\mathrm{Au}(\mathrm{III})$ compounds on colon cancer cell lines was not satisfactory. In 1996, four analogues of the $\mathrm{Au}(\mathrm{III})$ complex [AuCl2(damp)] (damp = 2-[(dimethylamino)methyl]-phenyl) (2a-e) were evaluated for antitumor activity. The compounds have structural features in common with cisplatin, which was included as a comparison in the study (Figure 1). The derivatives have been tested on a panel of cell lines, among others made from human colorectal cancer such as: SW620, SW1116, SW403, HT29/219. The comparison of results for Au(III) compounds and cisplatin showed broadly similar growth-inhibiting properties and differential cytotoxicity, and the SW620 and SW1116 lines were the least sensitive to the compounds (Table 1). Therefore, these complexes might have the potential as an antitumor agent but in selected cancer types. In addition, although some compounds had some structural similarity to cisplatin, their mode of action seemed different [98]. Furthermore, the organogold compounds studied exhibit good stability within a physiological-like environment. Subsequent chemical and biological studies of $\mathbf{2 a - e}$ derivatives also confirmed the same properties [99].
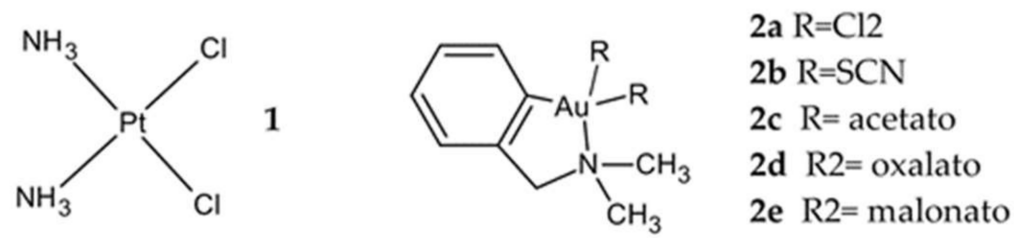<smiles>[R][X]([R])([R])c1ccccc1Cc1ccccn1</smiles>

$4 \mathrm{R}=$ Thiosalicylate

Figure 1. Structural comparison of organogold derivatives $2 \mathbf{a}-\mathbf{e}, \mathbf{4}$ with cisplatin (1).

Table 1. Comparison of $\mathrm{IC}_{50}(\mu \mathrm{M})$ for complexes $\mathbf{2 a}-\mathbf{2 e}$ and cisplatin (1) against selected human cell lines [98].

\begin{tabular}{ccccccc}
\hline Symbol & $\begin{array}{c}\text { SW620 } \\
\text { (Colon) }\end{array}$ & $\begin{array}{c}\text { SW1116 } \\
\text { (Colon) }\end{array}$ & $\begin{array}{c}\text { HT29/219 } \\
\text { (Rectum) }\end{array}$ & $\begin{array}{c}\text { ZR-75-1 } \\
\text { (Breast) }\end{array}$ & $\begin{array}{c}\text { HT-1376 } \\
\text { (Bladder) }\end{array}$ & $\begin{array}{c}\text { SK-OV-3 } \\
\text { (Ovary) }\end{array}$ \\
\hline $\mathbf{1}$ & 167 & 163 & 17 & 27 & 23 & 23 \\
$\mathbf{2 a}$ & 124 & 119 & 55 & 34 & 30 & 45 \\
$\mathbf{2 b}$ & 51 & 47 & 25 & 45 & 6,7 & 20 \\
$\mathbf{2 c}$ & 281 & 238 & 67 & 41 & 13 & 13 \\
$\mathbf{2 d}$ & 205 & 215 & 19 & 36 & 10 & 10 \\
$\mathbf{2 e}$ & 67 & 80 & 36 & 27 & 11 & 11 \\
\hline
\end{tabular}

Calamai et al. designed, synthesized and evaluated for cytotoxicity four complexes (3a-3d, Figure 2) with a square-planar geometry, like cisplatin. The experiment was performed on a panel of five tumor cell lines, composed mainly of cell lines sensitive to cisplatin, e.g., HCT-8 with cisplatin and sodium tetrachloroaurate $\left(\mathrm{NaAuCl}_{3}\right)$ as control. In a colon cancer cell line, all four investigated derivatives exhibited less cytotoxic effect (with $\mathrm{IC}_{50}$ ranging from 8 to $29 \mu \mathrm{M}$ ) than cisplatin ( $\mathrm{IC}_{50}$ value $3.9 \mu \mathrm{M}$ ). On the contrary, their antitumor potency against other tumor cell lines was comparable to or even greater than cisplatin (Table 2) [84]. 
<smiles></smiles><smiles>CN1C=C2C=CC=CC2O[Al]1(Cl)Cl</smiles>

$3 c$

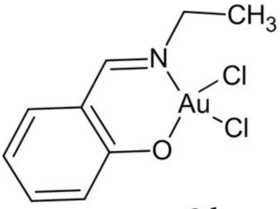

$3 d$

Figure 2. Au complexes 3a-d with a square-planar geometry.

Table 2. Characterization of the anticancer properties of new organogold compounds.

\begin{tabular}{|c|c|c|c|}
\hline Symbol & Proposed Mechanism of Action & Cell Line & IC $_{50}$ Range $(\mu \mathrm{M})$ \\
\hline $3 a-d$ & Bind to DNA & НCT8 & $\begin{array}{c}8.0 \pm 2.5(3 \mathbf{a}) \\
11.6 \pm 2.0(3 \mathbf{b}) \\
29(\mathbf{3 c}) \\
28.5(3 \mathbf{d}) \\
3.9 \pm 0.6 \text { (cisplatin) }\end{array}$ \\
\hline 4 & Inhibition of cathepsins $\mathrm{B}$ and $\mathrm{K}$ & $\begin{array}{c}\text { DLD-1 } \\
\text { HCT-116 } \\
\text { HT-29 }\end{array}$ & $\begin{array}{c}3.5 \text { (DLD-1) } \\
5.7 \text { (HCT-116) } \\
11.7(\text { HT-29) }\end{array}$ \\
\hline $5 a, b$ & Undetermined & $\begin{array}{l}\text { Caco-2 } \\
\text { HT-29 }\end{array}$ & $\begin{array}{l}>120(5 \mathbf{a}, \mathbf{b}) \\
39.8(5 \mathbf{a}) \\
>120(5 \mathbf{b})\end{array}$ \\
\hline 6 & $\begin{array}{l}\text { Intercalation of DNA, inhibition } \\
\text { of topoisomerase I, II }\end{array}$ & SW620 & 15 \\
\hline 7 & Undetermined & LS-174T & 74.0 \\
\hline $8 a-d$ & Undetermined & HT-29 & $\begin{aligned} 5.2 & \pm 0.4(\mathbf{8 a}) \\
18.1 & \pm 0.6(\mathbf{8 b}) \\
17.7 & \pm 0.4(\mathbf{8 c}) \\
33.7 & \pm 2.2(\mathbf{8 d})\end{aligned}$ \\
\hline $8 e, g$ & $\begin{array}{c}\text { Induction of apoptosis, G0/G1 } \\
\text { cell cycle arrest }\end{array}$ & HCT-116 & $\begin{array}{l}47.0 \pm 3.1(\mathbf{8 e}) \\
67.0 \pm 4.8(\mathbf{8 f}) \\
14.9 \pm 0.6(\mathbf{8 g})\end{array}$ \\
\hline $9 a-d$ & Undetermined & LoVo & $\begin{array}{c}(2.40 \pm 0.04) \times 10^{-2}(\mathbf{9 a}) \\
3.8 \pm 0.1(\mathbf{9 b}) \\
7.6 \pm 0.2(\mathbf{9 c}) \\
7.9 \pm 0.1(\mathbf{9 d})\end{array}$ \\
\hline $10 a, b$ & $\begin{array}{c}\text { Induction of ROS-dependent } \\
\text { opening of the PTP. }\end{array}$ & HCT-116 & $\begin{array}{r}15.8 \pm 2.1(\mathbf{1 0 a}) \\
43.6 \pm 5.4(\mathbf{1 0 b})\end{array}$ \\
\hline 11 & $\begin{array}{l}\text { Modification of MtMP, release of } \\
\text { cytochrome C to the cytoplasm, } \\
\text { caspase- } 3 \text { activation; } \\
\text { inhibition of proteasome. }\end{array}$ & Сaco-2/TC7 & $\begin{array}{c}1.00 \pm 0.06(11) \\
45.6 \pm 8.08 \text { (cisplatin) } \\
2.1 \pm 0.4 \text { (auranorfin) }\end{array}$ \\
\hline 12 & Distortion of DNA double helix & HCT-116 & \\
\hline 13 & $\begin{array}{l}\text { Inhibition of the zinc-finger } \\
\text { protein PARP-1 }\end{array}$ & $\begin{array}{l}\text { HCT116 p53+/+ } \\
\text { HCT116 p53-/- }\end{array}$ & $\begin{array}{r}2.1 \pm 0.7 \\
14.0 \pm 1.1\end{array}$ \\
\hline $14 a, b$ & $\begin{array}{l}\text { 14a proapoptotic activation, } \\
14 \mathrm{~b} \text { pronecrotic actions }\end{array}$ & $\begin{array}{c}\text { HCT116 } \\
\text { HCT116p53-/- }\end{array}$ & $\begin{array}{l}0.48 \pm 0.57(\mathbf{1 4 a}) \\
0.33 \pm 0.14(\mathbf{1 4 b}) \\
0.23 \pm 0.20(\mathbf{1 4 a}) \\
0.27 \pm 0.12 \mathbf{( 1 4 b )}\end{array}$ \\
\hline 15 & $\begin{array}{l}\text { Molecular target: } \\
\text { sulfur-containing } \\
\text { proteins }\end{array}$ & WiDr & $9.8 \pm 1.2$ \\
\hline 16 & Undetermined & HCT116 & $>50$ \\
\hline
\end{tabular}


Cytostatic activity for square-planar cycloaurated Au(III) compounds on HCT-116 and HT29 cell lines was also studied. The most active thiosalicylate derivative 4 (Figure 1), with $\mathrm{IC}_{50}$ value $11.7 \mu \mathrm{M}$ for HT29, was further tested in vivo. Additionally, it was proposed that the molecular targets of these compounds are thiol-containing biological molecules such as the cathepsin cysteine proteases, and it was found that they are able to inhibit both cathepsins B and K [100].

The cytotoxicity of two sterically different bithiazole $\mathrm{Au}(\mathrm{III})$ complexes, regular squareplanar compound 5a and disordered square-pyramidal geometry in 5b (Figure 3), was also investigated. Of the three cancer cell lines studied, derivative 5a showed no cytotoxicity in Caco-2, but its toxicity in HT29 was similar to cisplatin (Table 2). Compound $\mathbf{5 b}$ had no anticancer value because it exhibited very little toxicity on the studied cell lines. This lack of activity might be due to steric construction [101].

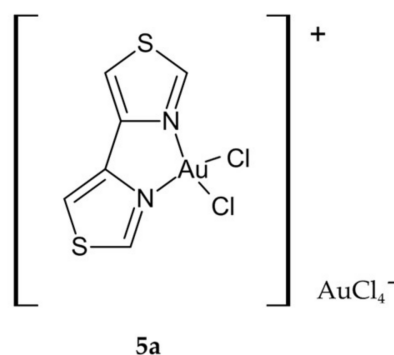

5 a

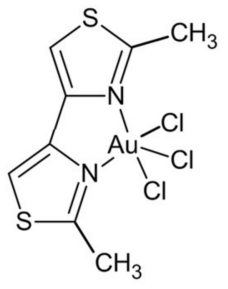

$5 b$

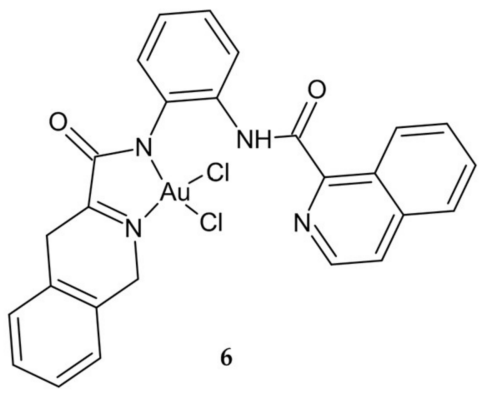

Figure 3. Au derivatives $5 \mathbf{a}, \mathbf{b}$ and $\mathbf{6}$.

Wilson et al. reported that out of a series of four square-planar $\mathrm{Au}(\mathrm{III})$ chelates, only isoquinolylamidogold(III) chelate 6 (Figure 3) was sufficiently cytotoxic in the single-dose assay and promising for further studies. The data indicate that seven different colon cell lines were among the most susceptible to the $\mathrm{Au}(\mathrm{III})$ complex, with $\mathrm{IC}_{50}$ values below $20 \mu \mathrm{M}$. The lowest $\mathrm{IC}_{50}$ value was for the colon cancer cell line SW-620 (Table 2). The cytotoxicity of the investigated compound compares favorably with that of cisplatin and etoposide (a nonintercalating topoisomerase II inhibitor). Dual topoisomerase I and II inhibitors were given as the mechanism of action of the compounds. However, there is a need to improve the structure of the chelates so that they are less susceptible to precipitation from aqueous solutions, which may increase their cytotoxicity and thus the chances of further development [85].

Another approach was presented by researchers who synthesized a new bile acid cholylglycinato Au(III) complex 7 (Figure 4) based on the ability of bile acids for vectorializing the cytostatic activity of other agents. Cytostatic effect of the investigated compound was mild against human colon adenocarcinoma LS-174T in vitro, but 7 had a significantly higher $\mathrm{IC}_{50}$ value than cisplatin (Table 2). The appearance of colloidal Au during the process of hydrolysis under physiological conditions may explain the low cytostatic activity [102].<smiles>[R]C(=O)NCC(=O)O[Al]1OC(=O)CN1C([R])O</smiles>

Figure 4. A new bile acid cholylglycinato Au(III) complex 7.

Investigations of the cytotoxicity scores of novel organogold (III) compounds 8a-d (Figure 5) revealed that all of these compounds, except for $\mathbf{8 d}$, are generally stable under physiological conditions and exhibit significant cytotoxic properties on a limited panel of 
human tumor cell lines. However, negligible anticancer effects (Table 2) were generally measured on the HT29 line compared to those of cisplatin and oxaliplatin [103]. Massai et al. published further work on derivatives of these cyclometallated complexes 8e,g (Figure 5). All three compounds, especially $\mathbf{8 g}$, cause moderate, but still significant. antiproliferative effects toward HCT-116 cancer cells, accompanied by a strong induction of apoptosis and a G0/G1 cell cycle arrest (Table 2). Given the fact that all these effects were greater on CRC cell line HCT-116 compared to the normal L-929 fibroblast cell line, there is a possibility to further investigate and characterize $\mathbf{8 g}$ as a potential anticancer agent on a larger and more complex panel of cancer cell lines, as well as to evaluate the mechanisms of its different toxicity effects between in vitro models of tumoral and healthy tissue [104].

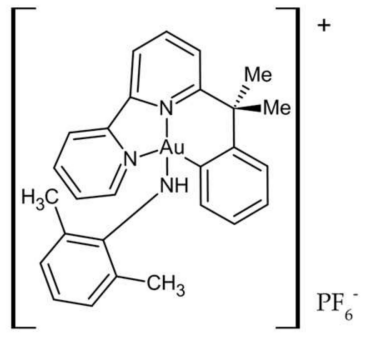

8<smiles>Cl[W](Cl)(Cl)c1cnn(-c2ccccc2)c1</smiles>
$8 d$

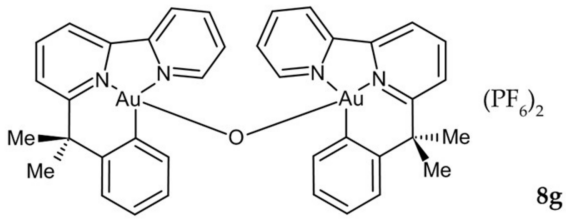

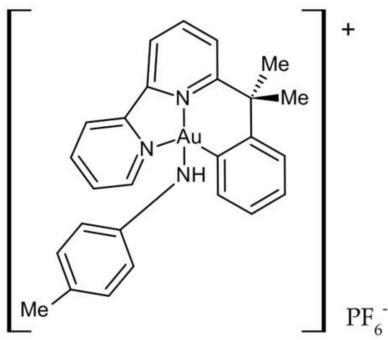

$8 \mathrm{~b}$<smiles>CO[C@H]1c2ccccc2C(C)(C)c2cccc[n+]21</smiles>
a

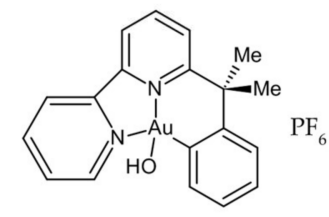

8 e

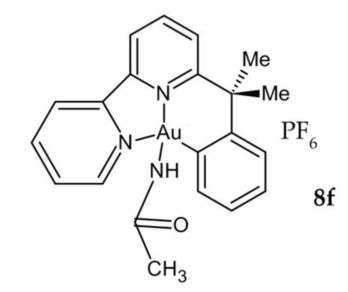

Figure 5. Novel organogold (III) compounds 8a-g.

Considering the ability of dithiocarbamates to act as chelating ligands, many examples of $\mathrm{Au}(\mathrm{III})$ dithiocarbamate derivatives have been reported. The first more promising studies on the cytotoxic activity of $\mathrm{Au}$ (III) compounds in CRC were published by Ronconi et al., which described some of $\mathrm{Au}(\mathrm{I})$ and $\mathrm{Au}(\mathrm{III})$ complexes with dithiocarbamate ligands (DMDT = N,Ndimethyldithiocarbamate; DMDTM = S-methyl-N,N-dimethyldithiocarbamate; ESDT = thylsarcosinedithiocarbamate). Their preliminary studies have shown that the biological activity of the compounds should generally be attributed to the presence of the $\mathrm{Au}(\mathrm{III})$ metal center, and that the $\mathrm{Au}(\mathrm{I})$ compounds produce a less pronounced inhibition of cell growth compared to Au(III) analogues. Four complexes 9a-d (Figure 6) were selected for further in vitro cytotoxicity testing. Data regarding their in vitro antiproliferative activity against colon adenocarcinoma cell lines (LoVo), which are notoriously not very sensitive to cisplatin, are extremely interesting, because these new $\mathrm{Au}(\mathrm{III})$ complexes seem to also be cytotoxic against tumor cell lines resistant to cisplatin, overcoming their intrinsic resistance and supporting the hypothesis of a different mechanism of action. The $\mathrm{IC}_{50}$ values of investigated compounds ranged from $2.4 \mathrm{nM}$ to $7.9 \mu \mathrm{M}$ (Table 2), while cisplatin's $\mathrm{IC}_{50}$ value was $56 \mu \mathrm{M}[105,106]$. 


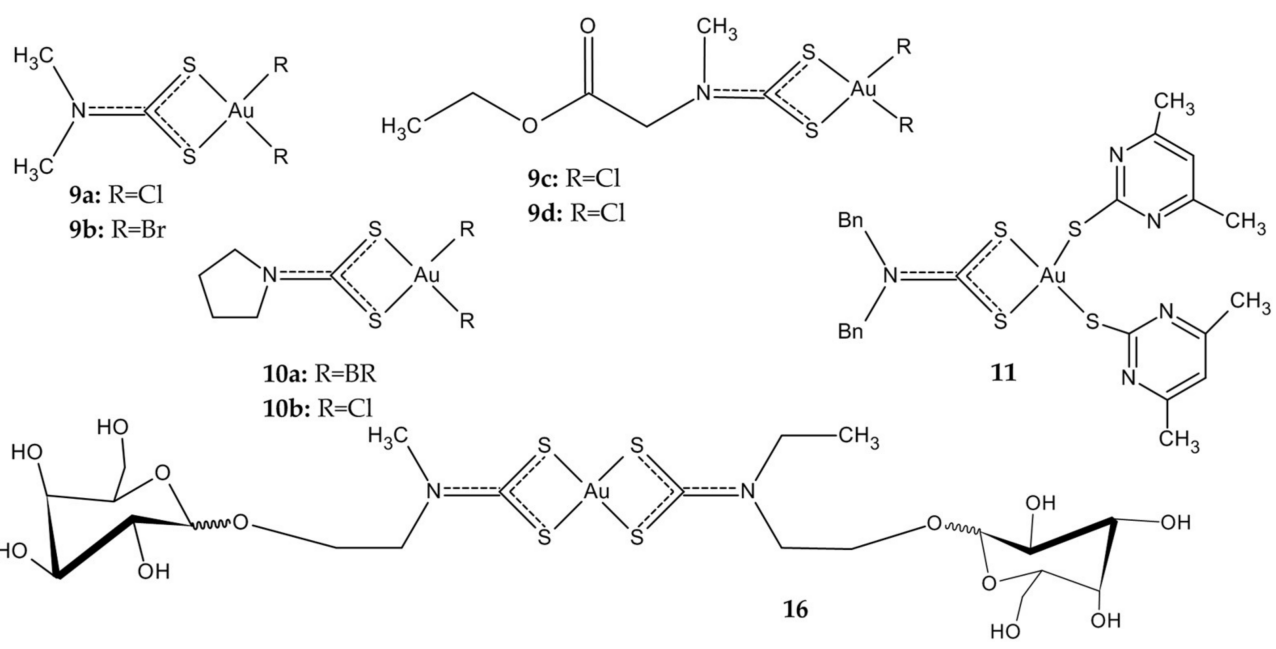

Figure 6. $\mathrm{Au}(\mathrm{III})$ dithiocarbamate derivatives $\mathbf{9 a}-\mathrm{d}, \mathbf{1 0 a}, \mathbf{b}, \mathbf{1 1}, \mathbf{1 6}$.

Treatment with the other two $\mathrm{Au}(\mathrm{III})$ compounds based on the pyrrolidinedithiocarbamates (PDT), 10a,b (Figure 6), showed a rapid (three-hour) dose-dependent decrease in cell viability in the HCT-116 colorectal carcinoma cells. It was found that the bromide derivative 10a was more effective than the chloride one $10 \mathrm{~b}$ in inducing cell death and acting via elicited oxidative stress, with effects on the permeability transition pore, a mitochondrial channel whose opening leads to cell death (Table 2). Cisplatin did not show any cytotoxicity under the same experimental conditions [107]. Greater cytotoxicity of bromides is in agreement with the findings reported by Casini et al. [108] for other $\mathrm{Au}(\mathrm{III})$ anticancer agents.

Mixed thiolate-dithiocarbamate $\mathrm{Au}(\mathrm{III})$ complexes display high antiproliferative activity against colon cancer cell line Caco-2/TC7, without affecting differentiated enterocytes. The most promising derivative $\mathbf{1 1}$ (Figure 6) is characterized by a much higher cytotoxicity compared to cisplatin, and slightly higher than auranorfin (Table 2). Although it was assumed that TrxR was a potential target of the dithiocarbamate Au complexes, this was not supported, as reactive oxygen species (ROS) levels and TrxR activity remained unchanged during the experiment. Cell death studies showed that the complexes induced changes in mitochondrial membrane potential, cytochrome $C$ release and caspase- 3 activation. The complexes are characterized by high stability under physiological conditions, which gives the opportunity to develop new cytostatics in the treatment of colorectal cancer with the proteasome as a possible target [88].

Another study showing high cytotoxicity against the colon cancer cell line was reported by Shi et al. Compared to cisplatin, Au(III) compound 12 (Figure 7) has demonstrated higher cytotoxicity for HCT-116 cell lines at all the concentrations used in the studies. At the concentration of $106 \mathrm{M}$, the compound showed 30\% inhibition against the HCT-116 cell line, while at the same concentration, cisplatin shows $20 \%$ inhibition. Additionally, it has been shown that the compound $\mathbf{1 2}$ can induce DNA double helix distortion in its mechanism of action [86].

The new $\mathrm{Au}(\mathrm{III})$ cyclometallated phosphine derivative 13, with PTA = 1,3,5-triazaphosphaadamantane ligand (Figure 7), which is not cytotoxic but is known in general to improve water solubility, has been proposed as a new antineoplastic agent in colorectal cancer. The derivative $\mathbf{1 3}$ was the most active of all investigated complexes in the study, twice as toxic as cisplatin against HCT-116 p53+/+ cells, and poorly effective on HCT-116 p53-/(Table 2). This result suggests a similar dependence on p53 pathways for $\mathrm{Au}(\mathrm{III})$ complex as for cisplatin. Interestingly, compound $\mathbf{1 3}$ inhibited the zinc finger enzyme PARP-1 in $\mathrm{nM}$ concentrations, suggesting the possible design of selective inhibitors and the use of organometallic Au compounds in combination therapies with other anticancer drugs [89]. 
<smiles>Cl[C@H]1CCNCCN[C+](Cl)(Cl)N1</smiles>
12<smiles></smiles><smiles></smiles>

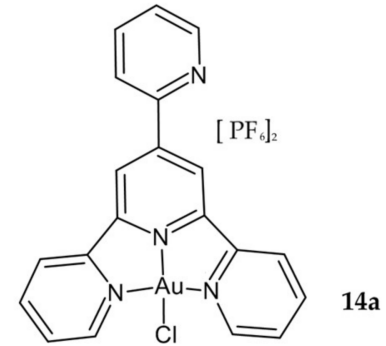

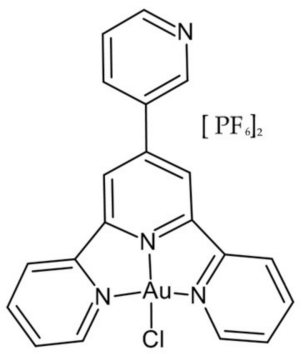

Figure 7. $\mathrm{Au}(\mathrm{III})$ complexes 12, 13, 14a,b, 15.

Both $\mathrm{Au}(\mathrm{III})$ complexes 14a and $14 \mathbf{b}$ incorporating $2,2^{\prime}: 6^{\prime}, 2^{\prime \prime}$-terpyridine ligand (Figure 7), showed excellent antiproliferative activities against HCT-116, higher than the free ligands and cisplatin. Additionally, compound 14a showed high selectivity against HCT-116 and HCT-116p53 - / - cells, confirmed by the selectivity index (SI). Most interestingly, the complex 14a exhibited proapoptotic activation, while $\mathbf{1 4 b}$ displayed pronecrotic actions [109].

$\mathrm{Au}(\mathrm{III})$ complexes containing quinoline ligands at position 8 with different groups arose due to the broad spectrum of medical applications of 8-hydroxyquinoline. It was found that compound $\mathbf{1 5}$ with an N-tosyl-8-aminoquinoline ligand (Figure 7) is the most active of the synthesized complexes in all cancer cell lines tested, including the cisplatinresistant WiDr cell line, and acts by interacting with proteins. Moreover, this complex has proved to be the most stable compound in DMSO and saline solution, even after several hours [110].

The latest available work in this area describes $\mathrm{Au}(\mathrm{III})$ complexes with glycoconjugated dithiocarbamato ligands (among others 16, Figure 6). To improve the selective accumulation of an anticancer metal payload in malignant cells, carbohydrates (D-glucose, D-galactose, and D-mannose) were chosen as targeting agents exploiting the Warburg effect that accounts for the overexpression of glucose-transporter proteins (in particular GLUTs) in the phospholipid bilayer of most cancer cells. Unfortunately, the collected results indicate that the $\mathrm{Au}$ (III) complexes are not good substrates for GLUT and are inactive toward HCT-116 cells, with $\mathrm{IC}_{50}$ values higher than $50 \mu \mathrm{M}$ (Table 2) [111].

\subsection{Porphyrin Complexes}

More comprehensive and promising results were presented by using porphyrin ligand, which can stabilize the $\mathrm{Au}(\mathrm{III})$ ion against demetallation and reduction by the biological reductant glutathione [112].

Preliminary studies of a series of $\mathrm{Au}(\mathrm{III})$ tetraarylporphyrin (TPP) derivatives confirmed their stability in the presence of glutathione and demonstrated a much greater potency than cisplatin in killing human cancer cells, including drug-resistant variants [113]. The 17 complex (Figure 8) was selected for further study of its antitumor activity and its mechanism against colon cancer. The investigated compound exhibited marked cytotoxicity against different colon cancer cell lines and $\mathrm{IC}_{50}$ values with 9-fold to 21-fold greater potency than that of cisplatin (Table 3). Furthermore, the 17 complex significantly induced apoptosis and cell cycle arrest and cleaved caspase 3, caspase 7, and poly(ADP-ribose) polymerase; released cytochrome C, and upregulated p53, p21, p27, and Bax. Further- 
more, in vivo tests were also carried out [114]. The same complex was further studied by Altaf et al. with promising results. Compound $\mathbf{1 7}$ showed very high activity compared to $\mathrm{Au}$ (III) complexes of meso-1,2-di(1-naphthyl)-1,2-diaminoethane and cisplatin. It was about 7-8 times more potent than cisplatin against the HCT-15 cancer cell [115].

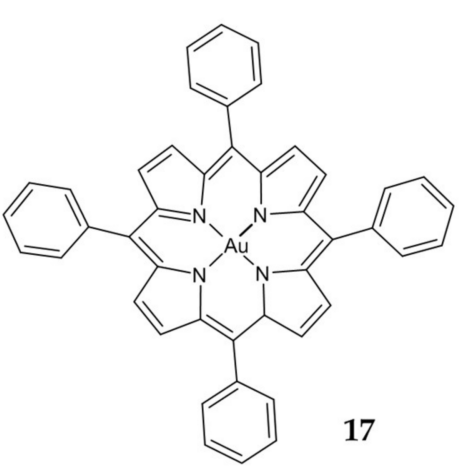

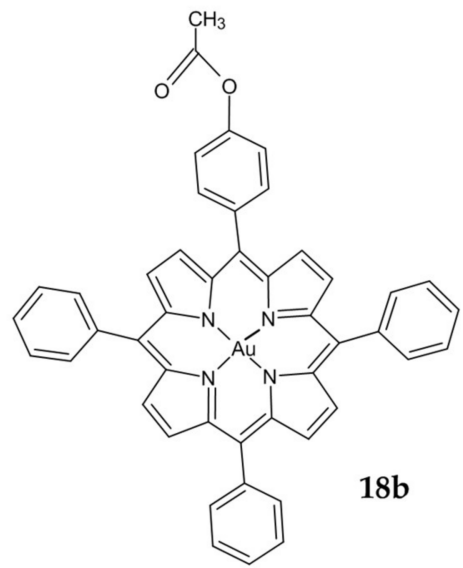

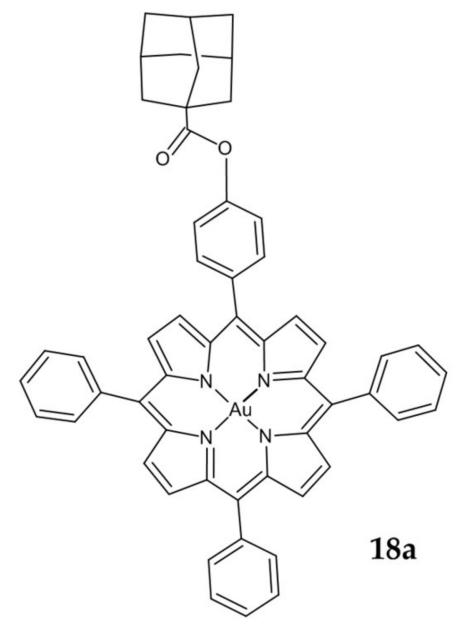

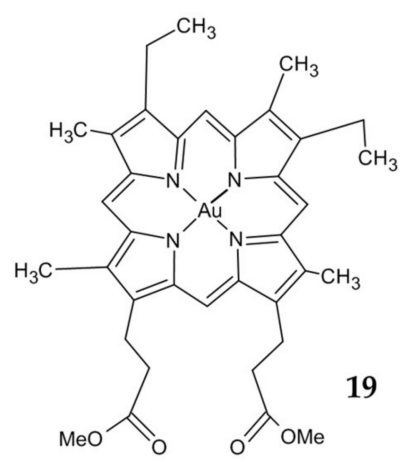

Figure 8. Au(III) porphyrin complexes 17, 18a,b, 19.

Table 3. Characterization of the anticancer properties of porphyrin complexes.

\begin{tabular}{cccc}
\hline Symbol & $\begin{array}{c}\text { Proposed Mechanism of } \\
\text { Action }\end{array}$ & Cell Line & IC $_{\mathbf{5 0}}$ Range $(\boldsymbol{\mu M})$ \\
\hline $\mathbf{1 7 a}-\mathbf{e}$ & $\begin{array}{c}\text { Inducing apoptosis by a } \\
\text { mitochondrial death } \\
\text { pathway }\end{array}$ & SW1116 & $0.20 \pm 0.02$ \\
& Colo 205 & $0.27 \pm 0.02$ \\
& CRL-238 & $1.41 \pm 0.20$ \\
& CCL-2134 & $0.65 \pm 0.13$ \\
& HCT-15 & $0.86 \pm 0.15$ \\
$\mathbf{1 8 a} \mathbf{b}$ & Inducing apoptosis by & HCT-15A2 & $3.43 \pm 0.46$ \\
& intrinsic pathway & HCT-116 & $17.0(\mathbf{1 8 a})$ \\
& & & $3.5(\mathbf{1 8 b})$ \\
& & HCT-116 & $3.0(\mathbf{1 8 a})$ \\
\hline $\mathbf{1 9}$ & Inhibition the Trx, & $0.06 \pm 0.01$ \\
& peroxiredoxin and & NCM460 & $1.5 \pm 0.15$ \\
& deubiquitinases & & \\
\hline
\end{tabular}

A novel $\mathrm{Au}(\mathrm{III})$ porphyrin analogs $\mathbf{1 8 a}$ and $\mathbf{1 8 b}$ (Figure 8) were prepared by modifying one of the peripheral phenyl groups of $\mathbf{1 7}$. Results revealed that $\mathbf{1 8 b}$ was more cytotoxic to the colon cancer line than 18a (Table 3). The investigated complexes reduced the survival of human CRC HT-29 and HCT-116 cell lines, caused cell cycle arrest in the G2/M phase, 
and decreased expression of cyclin B1 and cyclin-dependent kinase 1 (Cdk1) was observed with an increase in regulation of the active form of p53, p21, and Bcl-2 associated with $X$ (Bax) [87]. Furthermore, they induced apoptosis by the intrinsic pathway, as previously described [114].

Tong et al. demonstrate an anticancer activity of $\mathrm{Au}(\mathrm{III})$ mesoporphyrin IX dimethyl ester (19) (Figure 8). This compound displayed a higher cytotoxicity in HCT-116 colon cancer cells compared to noncancerous colon epithelial cells (NCM460) with 25-fold differences in $\mathrm{IC}_{50}$ values (Table 3). Promising results from in vivo studies were also reported. The mechanism of action involves modification of the reactive cysteine residues and inhibiting the activity of thioredoxin, peroxiredoxin and deubiquitinases. Crucially, this study revealed that $\mathrm{Au}(\mathrm{III})$ induced ligand scaffold reactivity to target the thiol, which could be a useful tool in oncology [93].

\subsection{N-Heterocyclic Carbenes (NHCs) Derivatives}

A large part of the reviewed papers concerns research on N-heterocyclic carbenes (NHCs) Au complexes. It is widely accepted that the replacement of phosphine ligands by the isolobal NHC ligands frequently improves the properties of the new compounds for practical applications, which are them being water- and air-stable and easier to handle. Moreover, the imidazolium salts as the ligand precursor can be functionalized with almost any substituent, a rarely accessible feature in phosphines [116].

Lemke et al. described the synthesis and antiproliferative activity of a new halide, amino acid and dipeptide NHC $\mathrm{Au}(\mathrm{I})$ and NHC $\mathrm{Au}(\mathrm{III})$ complexes. In vitro cytostatic effect of compound 20 (Figure 9) was only mild against human colon adenocarcinoma HT-29, with an $\mathrm{IC}_{50}$ value higher than most active complexes and slightly higher compared to cisplatin (Table 4) [116].<smiles>CN1C=CN(C(c2ccccc2)c2ccccc2)C1C(Br)(Br)Br</smiles>

20

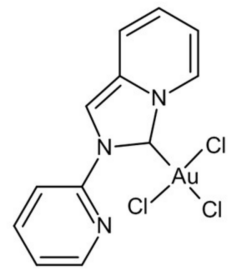

21

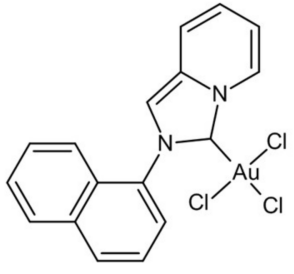

22

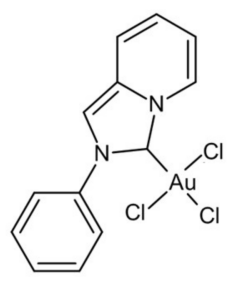

23<smiles>[R]c1ccc(C2=C(c3ccc([R])cc3)N(CC)C(C(Br)(Br)Br)N2[R])cc1</smiles>

24a $\mathrm{R}=\mathrm{MeO}, \mathrm{R} 1=\mathrm{Et}$ $24 \mathrm{~b} R=\mathrm{F}, \mathrm{R} 1=\mathrm{Et}$<smiles>[R]c1ccc(C2=C(c3ccc([R])cc3)N(CC)C(N(I)[Al](I)(I)C3N(CC)C(c4ccc([R])cc4)=C(c4ccc([R])cc4)N3CC)N2CC)cc1</smiles>

$24 \mathrm{c}=\mathrm{OCH}_{3}$ 24d $R=F$

Figure 9. NHCs $\mathrm{Au}(\mathrm{III})$ derivatives 20-24.

Other groups were evaluated in vitro for the cytotoxicities of Au and Ag NHCs complexes supported by a pyridine, annulated imidazole-2-ylidene (21) [117,118], imidazolium salt 1-naphthyl-2-pyridin-2-yl-2H-imidazo[1,5-a]pyridin-4-ylium hexafluorophosphate (22) [119], pyridyl[1,2-a]\{2-acetylylphenylimidazol\}-3-ylidene (23) [120] (Figure 9). All complexes of $\mathrm{Au}(\mathrm{III})-\mathrm{NHC}$ exhibited lower cytotoxicity than $\mathrm{Ag}(\mathrm{I})$ and $\mathrm{Au}(\mathrm{I})$ complexes for nearly all cell lines tested. Despite that, compounds 21, 22, and 23 were more potent 
than cisplatin against the HCT-116 cell line (Table 4). Unfortunately, due to the lower cytotoxicity of $\mathrm{Au}(\mathrm{III})-\mathrm{NHC}$, studies involving the mechanism of action have not been performed for this complex.

Table 4. Characterization of the anticancer properties of N-heterocyclic carbenes (NHCs).

\begin{tabular}{cccc}
\hline Symbol & Proposed Mechanism of Action & Cell Line & IC $_{\mathbf{5 0}}$ Range $(\boldsymbol{\mu M} \mathbf{M}$ \\
\hline $\mathbf{2 0}$ & Undetermined & HT-29 & $12.7 \pm 1.2$ \\
\hline $\mathbf{2 1}$ & Undetermined & HCT-116 & $5.9 \pm 3.6$ \\
\hline $\mathbf{2 2}$ & Undetermined & HCT-116 & $6.78 \pm 2.01$ \\
\hline $\mathbf{2 3}$ & Undetermined & HCT-116 & $21.25 \pm 1.37$ \\
\hline $\mathbf{2 4 a}, \mathbf{b}$ & Inhibition of TrxR & HT-29 & $6.2 \pm 1.0(\mathbf{2 4 a})$ \\
& & & $7.5 \pm 2.9(\mathbf{2 4 b})$ \\
\hline $\mathbf{2 4 c , d}$ & Undetermined & HT-29 & $0.26 \pm 0.03(\mathbf{2 4 c})$ \\
& & & $0.30 \pm 0.01(\mathbf{2 4 d})$ \\
\hline $\mathbf{2 5 a}-\mathbf{g}$ & Multiple molecular targets & HCT-116 & $4.40 \pm 1.50(\mathbf{2 5 a})$ \\
& & & $1.10 \pm 0.28(\mathbf{2 5 b})$ \\
& & & $0.49 \pm 0.12(\mathbf{2 5 c})$ \\
& & & $0.23 \pm 0.11(\mathbf{2 5 d})$ \\
& & & $0.25 \pm 0.10(\mathbf{2 5 e})$ \\
& & & $0.52 \pm 0.34(\mathbf{2 5 f})$ \\
& & & $0.20 \pm 0.06(\mathbf{2 5 g})$ \\
\hline
\end{tabular}

Liu et al. have proposed NHC-Au halide complexes derived from 4,5-diarylimidazoles. The influence of the oxidation state of the metal $(\mathrm{Au}(\mathrm{I})$ or $\mathrm{Au}(\mathrm{III}))$ is relatively low in general, however, on the HT-29 cell line, the Au(III) complexes $24 \mathbf{a}$ and $\mathbf{2 4 b}$ (Figure 9) were less active than their $\mathrm{Au}(\mathrm{I})$ congeners, which coincides with earlier papers. All complexes inhibit TrxR with different $\mathrm{IC}_{50}$ values, nevertheless, other targets should be considered as part of the mode of action [121]. Researchers, encouraged by these promising results, have investigated the effect of halide exchange in $\mathrm{Au}-\mathrm{NHC}$ complexes on their pharmacological properties. The growth-inhibitory effect against HT-29 cells was more than 10-fold higher for complexes 24c and 24d (Figure 9) than that of cisplatin or 5-FU. Moreover, this effect was independent of the oxidation state of $\mathrm{Au}$ and type of halides. Although the investigated complexes were successfully accumulated in the neoplastic tissue and localized in large amounts in the cell nucleus, their mode of action has not been clearly defined [122].

Fung et al. described the identification of multiple molecular targets for cyclometalated $\mathrm{Au}(\mathrm{III})$ complexes containing NHC ligands using photoaffinity groups. The $\mathrm{IC}_{50}$ values for complexes $25 \mathrm{a}-\mathrm{g}$ (Figure 10) ranged from $4.4 \mu \mathrm{M}$ to $0.2 \mu \mathrm{M}$ in comparison to cisplatin with an $\mathrm{IC}_{50}$ value $11.8 \mu \mathrm{M}$ (Table 4 ). Importantly, all the compounds showed much higher cytotoxicity to HCT-116 than to immortalized normal human hepatocyte (MIHA) cells, which may indicate their selectivity. Numerous tests showed the ability of complexes to bind to intracellular proteins such as mitochondrial heat shock protein 60 (HSP60), vimentin (VIM), nucleoside diphosphate kinase A (NDKA), nucleophosmin (NPM), nuclease-sensitive element binding protein ( $\mathrm{Y}$ box binding protein, $\mathrm{YB}-1$ ), and peroxiredoxin 1 (PRDX1). The fact that the complexes have multiple molecular targets can minimize the occurrence of drug resistance that is usually encountered with single-target anticancer agents due to naturally occurring genetic mutations [123]. 
<smiles>[R]N1C=CN([R])C1C1Nc2ccccc2-c2ccccc21</smiles><smiles>CN1Cc2ccccc2[C@]1(C)Cl</smiles>

\section{6}

\begin{tabular}{|c|c|c|c|c|c|c|c|}
\hline \multicolumn{2}{|r|}{$25 a$} & $25 b$ & $25 c$ & $25 d$ & $25 e$ & $25 \mathrm{f}$ & $25 \mathrm{~g}$ \\
\hline $\mathrm{R}^{1}$ & $\mathrm{CH}_{3}$ & $\mathrm{C}_{2} \mathrm{H}_{5}$ & $\mathrm{nC}_{3} \mathrm{H}_{7}$ & $\mathrm{nC}_{4} \mathrm{H}_{9}$ & $\mathrm{nC}_{5} \mathrm{H}_{11}$ & benzyl & $\mathrm{nC}_{4} \mathrm{H}_{9}$ \\
\hline $\mathrm{R}^{2}$ & $\mathrm{CH}_{3}$ & $\mathrm{C}_{2} \mathrm{H}_{5}$ & $\mathrm{nC}_{3} \mathrm{H}_{7}$ & $\mathrm{nC}_{4} \mathrm{H}_{9}$ & $\mathrm{nC}_{5} \mathrm{H}_{11}$ & benzyl & benzyl \\
\hline
\end{tabular}

Figure 10. Cyclometalated Au(III) complexes 25, 26.

\subsection{Chlorite-Cyanide Complex of Gold (III)}

Recently we characterized the synthesis, in vitro safety as well as anticancer activity of a novel chlorite-cyanide complex of gold (III) named TGS121 (patent no: PL422125A1). The compound was prepared as described by Krajewska et al. The obtained Au(III) complex with the formula $\left[\mathrm{Au}(\mathrm{CN})_{4}\right]_{2}\left(\mathrm{ClO}_{2}\right) \mathrm{Na}$ is a sodium salt of chloride dioxide associated with $\mathrm{Au}(\mathrm{III})$-cyanide group complex. This complex is water soluble, stable in a neutral $\mathrm{pH}$ and can be kept at room temperature. This complex turned out to be stable in cell culture medium and serum. Its relatively low molecular mass $(692.5 \mathrm{~g} / \mathrm{mol})$ and the form of sodium salt makes it stable in physiological fluids and enables the passage through biological membranes such as the cell membrane. The novel Au(III) compound turned out to exert cytostatic/cytotoxic effects in cancer Ha-Ras transfected NIH3T3 fibroblasts selectively in comparison to the noncancer NIH3T3 cells (Table 5). Since Ras isoforms share $80 \%$ identity and share similar activity-one can conclude that in CRC with Ras hyperactivation (mostly K-Ras) (like HCT116), the compound TGS121 would also be effective [124,125].

Table 5. Characterization of the anticancer properties of TGS121.

\begin{tabular}{cccc}
\hline Symbol & Proposed Mechanism of Action & Cell line & IC $_{\mathbf{5 0}}$ Range $(\boldsymbol{\mu M})$ \\
\hline \multirow{2}{*}{ TGS121 } & $\begin{array}{c}\text { Apoptosis induction, inhibition of Ras-mediated } \\
\text { pathway, cell cycle arrest at G2/M }\end{array}$ & Ras-3T3 & $0.231 \pm 1.2$ \\
& NIH3T3 & $5.05 \pm 2.6$ \\
\hline
\end{tabular}

\section{In Vivo Studies}

Promising cytotoxicity of many $\mathrm{Au}(\mathrm{III})$ complexes has been observed against tumor cells in vitro however, to our knowledge, there has been very little evaluation of these compounds on in vivo tumor models.

Thiosalicylate derivative of cycloaurated $\mathrm{Au}(\mathrm{III}) 4$ was tested in vivo against the colon HT29 tumor xenograft. Its cytotoxicity did not translate into in vivo pharmacological activity, with only modest inhibition of tumor growth. The lack of activity could in part be explained by the poor solubility of this complex, indicating that further work is necessary to improve both solubility and lipophilicity in order to improve biodistribution [100].

The second compound tested in vivo was an organogold(III) complex 26 (Figure 10), which exhibits promising in vitro cytotoxicity, but it failed to inhibit in vivo tumor growth in HT29 colon cancer xenografts [126].

Only two described Au(III) compounds exhibited favorable antitumor properties both in vitro and in vivo. The tetraarylporphyrin $\mathrm{Au}(\mathrm{III})$ complex 17, after intraperitoneal injec- 
tion in mice at doses of $1.5 \mathrm{mg} / \mathrm{kg}$ and $3.0 \mathrm{mg} / \mathrm{kg}$, significantly inhibited the proliferation of Colo205 tumor cells, induced apoptosis and inhibited colon cancer tumor growth [114]. The second one, Au(III) mesoporphyrin IX dimethyl ester 19, after intravenous injection twice per week for 21 days in nude mice bearing human colon cancer HCT-116 at doses 2 $\mathrm{mg} / \mathrm{kg}$, resulted in suppression of tumor growth by $72 \%$ compared to mice treated with vehicle control [93]. Acute toxicity studies have confirmed that the test compounds, in therapeutic concentrations, do not exhibit additional side effects in mice. Compound 19, after being transiently present in the liver and kidneys, was completely excreted in the urine. In contrast, complex 17 accumulated in the liver and kidneys with low urinary excretion [93]. The presented results suggest that these complexes may be a new potential therapeutic drug for colorectal cancer.

\section{Scope and Limitations}

This article is limited to gold compounds acting on human CRC cell lines, which might poorly represent the clinical disease. However, especially in CRC surgical treatment, neoadjuvant and adjuvant therapy is applied to reduce the micrometastatic area, and in this context, cell-based assays, especially clonogene assays, can mimic the in vivo situation [35]. We are observing a significant increase in publications on gold complexes. This indicates a great interest in this subject. Review work is also needed to systematize and summarize knowledge about this group of compounds.

\section{Conclusions}

Metallodrugs are very promising due to the fact that, depending on the choice of metal, its oxidation state, type, and number of coordinated ligands, we obtain a unique mechanism of drug action [72]. Therapies based on $\mathrm{Au}(\mathrm{III})$ compounds are particularly interesting and are currently being intensively developed due to their structural similarity to $\mathrm{Pt}(\mathrm{II})$ [28].

Colorectal cancer was shown to arise as a result of multiple genetic alternations in both oncogenes and tumor suppressor genes. If the initiated colon epithelium cells bearing mutations in APC or k-Ras can still control the DNA repair due to presence of active and functional p53, we talk about early and late adenoma-that is, nonmalignant and not-yet invasive. However, after genetic alternations that render the p53 pathway inactive, the initiated cells continue their unhampered divisions, despite DNA errors, and become malignant colon cancer cells [8]. That is why in colon cancer therapy, metal-based chemotherapeutics such as platin derivatives are used. Such drugs interfere with DNA, initiating cell-division catastrophe and subsequently cancer-cell death. The effectiveness of established metallodrugs is not always good due to resistance development in genetically instable cancer cells. In this context, novel drugs are needed.

The efficacy of $\mathrm{Au}(\mathrm{III})$ in the treatment of CRC has been proven in many in vitro assays using various colon cancer cell lines such as HT29, HT-116, COLO 205, and many others. $\mathrm{Au}(\mathrm{III})$ complexes are characterized by high efficiency, selectivity towards cancer cells, and compared to cisplatin display reduced toxicity, a broader spectrum of activity and the ability to overcome tumor resistance [57].

Given the structural and electronic similarity of $\mathrm{Au}(\mathrm{III})$ complexes to cisplatin and Ptrelated anticancer drugs, it was assumed that their mechanism of action involves binding to DNA. However, it appears that DNA may not be the primary biological target of $\mathrm{Au}(\mathrm{III})$ complexes due to studies reporting low DNA binding affinity [115]. Although TrxR inhibition was found to be the main pathway of potent antitumor activity of many Au-NHC complexes [127], the reviewed studies on Au(III)-NHC complexes do not support this mode of action. Notwithstanding the fact that we observe a great deal of scientific interest in Au compounds as drug candidates, we still have insufficient data to describe modes of action and the mechanisms they involve [128].

So far, only two Au(III) derivatives are characterized by high cytotoxicity for colon cancer cells, confirmed by both in vitro and in vivo assays. More advances in metallodrug 
studies are expected to improve the therapeutic potential of $\mathrm{Au}(\mathrm{III})$ in colorectal cancer treatment.

Author Contributions: Conceptualization, A.G. and P.T.; writing-original draft preparation, A.G.; writing-review and editing, P.T., I.M.-B. and M.S.; supervision, M.B.-Z.; funding acquisition, P.T. and J.F. All authors have read and agreed to the published version of the manuscript.

Funding: This research was supported by the grant from the National Science Center (2017/25/B/NZ5/ 02848 to J.F.) and the Medical University of Lodz (\#503/1-156-04/503-11-001-19 to J.F.). The research was funded by grant No. 1M15/3/M/MG/N/20 to P.T. The grant was supervised by I.M.-B. and was funded by a subsidy for science received by the Medical University of Warsaw.

Institutional Review Board Statement: Not applicable.

Informed Consent Statement: Not applicable.

Data Availability Statement: Data are contained within the article.

Conflicts of Interest: The authors declare no conflict of interest.

\section{References}

1. Bray, F.; Ferlay, J.; Soerjomataram, I.; Siegel, R.L.; Torre, L.A.; Jemal, A. Global cancer statistics 2018: GLOBOCAN estimates of incidence and mortality worldwide for 36 cancers in 185 countries. CA Cancer J. Clin. 2018, 68, 394-424. [CrossRef]

2. Sung, H.; Ferlay, J.; Siegel, R.L.; Laversanne, M.; Soerjomataram, I.; Jemal, A.; Bray, F. Global Cancer Statistics 2020: GLOBOCAN Estimates of Incidence and Mortality Worldwide for 36 Cancers in 185 Countries. CA Cancer J. Clin. 2021, 71, 209-249. [CrossRef]

3. Stewart, B.; Wild, C.P. World Cancer Report 2014; WHO: Geneva, Switzerland, 2014.

4. Parkin, D.M.; Bray, F.; Ferlay, J.; Pisani, P. Global Cancer Statistics, 2002. CA Cancer J. Clin. 2005, 55, 74-108. [CrossRef]

5. Ilyas, M.; Straub, J.; Tomlinson, I.P.M.; Bodmer, W.F. Genetic pathways in colorectal and other cancers. Eur. J. Cancer 1999, 35, 1986-2002. [CrossRef]

6. Rawla, P.; Sunkara, T.; Barsouk, A. Epidemiology of colorectal cancer: Incidence, mortality, survival, and risk factors. Prz. Gastroenterol. 2019, 14, 89-103. [CrossRef]

7. Sideris, M.; Papagrigoriadis, S. Molecular Biomarkers and Classification Models in the Evaluation of the Prognosis of Col-orectal Cancer. Anticancer Res. 2014, 34, 2061-2068. [PubMed]

8. Fearon, E.R.; Vogelstein, B. A genetic model for colorectal tumorigenesis. Cell 1990, 61, 759-767. [CrossRef]

9. Siegel, R.; DeSantis, C.; Virgo, K.; Stein, K.; Mariotto, A.; Smith, T.; Cooper, D.; Gansler, T.; Lerro, C.; Fedewa, S.; et al. Cancer treatment and survivorship statistics, 2012. CA: A Cancer J. Clin. 2012, 62, 220-241. [CrossRef] [PubMed]

10. Pawelec, G. Immunosenescence and cancer. Biogerontology 2017, 18, 717-721. [CrossRef]

11. Anisimov, V.N.; Sikora, E.; Pawelec, G. Relationships between cancer and aging: A multilevel approach. Biogerontology 2009, 10, 323-338. [CrossRef] [PubMed]

12. Brenner, H.; Kloor, M.; Pox, C.P. Colorectal cancer. Lancet 2014, 383, 1490-1502. [CrossRef]

13. Mármol, I.; Sánchez-De-Diego, C.; Pradilla Dieste, A.; Cerrada, E.; Rodriguez Yoldi, M. Colorectal Carcinoma: A General Overview and Future Perspectives in Colorectal Cancer. Int. J. Mol. Sci. 2017, 18, 197. [CrossRef]

14. Levin, B.; Lieberman, D.A.; McFarland, B.; Andrews, K.S.; Brooks, D.; Bond, J.; Dash, C.; Giardiello, F.M.; Glick, S.; Johnson, D.; et al. Screening and Surveillance for the Early Detection of Colorectal Cancer and Adenomatous Polyps, 2008: A Joint Guideline from the American Cancer Society, the US Multi-Society Task Force on Colorectal Cancer, and the American College of Radiology. CA Cancer J. Clin. 2008, 58, 130-160. [CrossRef] [PubMed]

15. Eaden, J.A.; Abrams, K.R.; Mayberry, J.F. The risk of colorectal cancer in ulcerative colitis: A meta-analysis. Gut 2001, 48, 526-535. [CrossRef] [PubMed]

16. Canavan, C.; Abrams, K.; Mayberry, J. Meta-analysis: Colorectal and small bowel cancer risk in patients with Crohn's disease. Aliment. Pharmacol. Ther. 2006, 23, 1097-1104. [CrossRef] [PubMed]

17. Martinez-Useros, J.; Garcia-Foncillas, J. Obesity and colorectal cancer: Molecular features of adipose tissue. J. Transl. Med. 2016, 14, 1-12. [CrossRef] [PubMed]

18. Willett, W.C. Diet and Cancer: An Evolving Picture. JAMA 2005, 293, 233-234. [CrossRef]

19. Pöschl, G.; Seitz, H.K. Alcohol and Cancer. Alcohol. Alcohol. 2004, 39, 155-165. [CrossRef] [PubMed]

20. Kuipers, E.J.; Grady, W.M.; Lieberman, D.; Seufferlein, T.; Sung, J.J.; Boelens, P.G.; Van De Velde, C.J.H.; Watanabe, T. Colorectal cancer. Nat. Rev. Dis. Primers 2015, 1, 15065. [CrossRef]

21. Singhal, S.; Nie, S.; Wang, M.D. Nanotechnology Applications in Surgical Oncology. Annu. Rev. Med. 2010, 61, 359-373. [CrossRef]

22. Kekelidze, M.; D’Errico, L.; Pansini, M.; Tyndall, A.; Hohmann, J. Colorectal Cancer: Current Imaging Methods and Future Perspectives for the Diagnosis, Staging and Therapeutic Response Evaluation. World J. Gastroenterol. 2013, 19, 8502. [CrossRef] [PubMed] 
23. Colussi, D.; Brandi, G.; Bazzoli, F.; Ricciardiello, L. Molecular Pathways Involved in Colorectal Cancer: Implications for Disease Behavior and Prevention. Int. J. Mol. Sci. 2013, 14, 16365-16385. [CrossRef]

24. Markowska, A.; Kasprzak, B.; Jaszczyńska-Nowinka, K.; Lubin, J.; Markowska, J. Noble Metals in Oncology. Contemp. Oncol. 2015, 19, 271. [CrossRef] [PubMed]

25. Ndagi, U.; Mhlongo, N.; Soliman, M.E. Metal Complexes in Cancer Therapy-an Update from Drug Design Perspective. Drug Des. Devel. Ther. 2017, 11, 599. [CrossRef] [PubMed]

26. Wang, A.Z.; Langer, R.; Farokhzad, O.C. Nanoparticle Delivery of Cancer Drugs. Annu. Rev. Med. 2012, 63, 185-198. [CrossRef] [PubMed]

27. Nanospectra Biosciences, Inc. A Pilot Study of AuroLase(Tm) Therapy in Patients with Refractory and/or Recurrent Tumors of the Head and Neck. 2016. Available online: clinicaltrials.gov (accessed on 15 December 2021).

28. Shaw, C.F. Gold-Based Therapeutic Agents. Chem. Rev. 1999, 99, 2589-2600. [CrossRef] [PubMed]

29. Mármol, I.; Quero, J.; Rodríguez-Yoldi, M.J.; Cerrada, E. Gold as a Possible Alternative to Platinum-Based Chemotherapy for Colon Cancer Treatment. Cancers 2019, 11, 780. [CrossRef]

30. Lee, M.M.; MacKinlay, A.; Semira, C.; Schieber, C.; Yepes, A.J.J.; Lee, B.; Wong, R.; Hettiarachchige, C.K.H.; Gunn, N.; Tie, J.; et al. Stage-based Variation in the Effect of Primary Tumor Side on All Stages of Colorectal Cancer Recurrence and Survival. Clin. Colorectal Cancer 2018, 17, e569-e577. [CrossRef]

31. Benson, A.B.; Venook, A.P.; Cederquist, L.; Chan, E.; Chen, Y.-J.; Cooper, H.S.; Deming, D.; Engstrom, P.F.; Enzinger, P.C.; Fichera, A.; et al. Colon Cancer, Version 1.2017, NCCN Clinical Practice Guidelines in Oncology. J. Natl. Compr. Cancer Netw. 2017, 15, 370-398. [CrossRef]

32. Van Cutsem, E.; Cervantes, A.; Nordlinger, B.; Arnold, D.; ESMO Guidelines Working Group. Metastatic colorectal cancer: ESMO Clinical Practice Guidelines for diagnosis, treatment and follow-up. Ann. Oncol. 2014, 25, iii1-iii9. [CrossRef]

33. Van Cutsem, E.; Nordlinger, B.; Cervantes, A. Advanced colorectal cancer: ESMO Clinical Practice Guidelines for treatment. Ann. Oncol. 2010, 21, v93-v97. [CrossRef]

34. Venook, A. Critical Evaluation of Current Treatments in Metastatic Colorectal Cancer. Oncol. 2005, 10, 250-261. [CrossRef]

35. Roth, M.T.; Zheng, S. Neoadjuvant Chemotherapy for Colon Cancer. Cancers 2020, 12, 2368. [CrossRef]

36. Cho, K.; Wang, X.; Nie, S.; Chen, Z.; Shin, D.M. Therapeutic Nanoparticles for Drug Delivery in Cancer. Clin. Cancer Res. 2008, 14, 1310-1316. [CrossRef]

37. Parveen, S.; Sahoo, S.K. Polymeric nanoparticles for cancer therapy. J. Drug Target. 2008, 16, 108-123. [CrossRef]

38. Balducci, L.; Ades, S. Faculty Opinions recommendation of Adjuvant chemotherapy for colon cancer in the elderly: Moving from evidence to practice. Oncology 2009, 23, 162. [CrossRef]

39. Banerjee, A.; Pathak, S.; Subramanium, V.D.; Dharanivasan, G.; Murugesan, R.; Verma, R.S. Strategies for targeted drug delivery in treatment of colon cancer: Current trends and future perspectives. Drug Discov. Today 2017, 22, 1224-1232. [CrossRef] [PubMed]

40. Prehn, R.T. The inhibition of tumor growth by tumor mass. Cancer Res. 1991, 51, 2-4. [PubMed]

41. Smith, B.H.; Gazda, L.S.; Conn, B.L.; Jain, K.; Asina, S.; Levine, D.M.; Parker, T.S.; Laramore, M.A.; Martis, P.C.; Vinerean, H.V.; et al. Hydrophilic Agarose Macrobead Cultures Select for Outgrowth of Carcinoma Cell Populations That Can Restrict Tumor Growth. Cancer Res. 2011, 71, 725-735. [CrossRef] [PubMed]

42. Ocean, A.J.; Parikh, T.; Berman, N.; Escalon, J.; Shah, M.A.; Andrada, Z.; Akahoho, E.; Pogoda, J.M.; Stoms, G.B.; Escobia, V.B. Phase I/II Trial of Intraperitoneal Implantation of Agarose-Agarose Macrobeads (MB) Containing Mouse Renal Adenocar-cinoma Cells (RENCA) in Patients (Pts) with Advanced Colorectal Cancer (CRC); American Society of Clinical Oncology: Aleksandria, VA, USA, 2013.

43. Suh, O.; Mettlin, C.; Petrelli, N.J. Aspirin use, cancer, and polyps of the large bowel. Cancer 1993, 72, 1171-1177. [CrossRef]

44. McDonald, B.F.; Quinn, A.M.; Devers, T.; Cullen, A.; Coulter, I.S.; Marison, I.W.; Loughran, S. In-vitro characterisation of a novel celecoxib microbead formulation for the treatment and prevention of colorectal cancer. J. Pharm. Pharmacol. 2015, 67, 685-695. [CrossRef]

45. Lev-Ari, S.; Strier, L.; Kazanov, D.; Madar-Shapiro, L.; Dvory-Sobol, H.; Pinchuk, I.; Marian, B.; Lichtenberg, D.; Arber, N. Celecoxib and Curcumin Synergistically Inhibit the Growth of Colorectal Cancer Cells. Clin. Cancer Res. 2005, 11, 6738-6744. [CrossRef] [PubMed]

46. Sah, B.; Vasiljevic, T.; McKechnie, S.; Donkor, O. Effect of probiotics on antioxidant and antimutagenic activities of crude peptide extract from yogurt. Food Chem. 2014, 156, 264-270. [CrossRef] [PubMed]

47. Choi, S.S.; Kim, Y.; Han, K.S.; You, S.; Oh, S.; Kim, S.H. Effects of Lactobacillus Strains on Cancer Cell Proliferation and Oxi-dative Stress in Vitro. Lett. Appl. Microbiol. 2006, 42, 452-458. [CrossRef] [PubMed]

48. Chong, E.S.L. A potential role of probiotics in colorectal cancer prevention: Review of possible mechanisms of action. World J. Microbiol. Biotechnol. 2013, 30, 351-374. [CrossRef] [PubMed]

49. Dasari, S.; Tchounwou, P.B. Cisplatin in cancer therapy: Molecular mechanisms of action. Eur. J. Pharmacol. 2014, 740, 364-378. [CrossRef]

50. Muhammad, N.; Guo, Z. Metal-based anticancer chemotherapeutic agents. Curr. Opin. Chem. Biol. 2014, 19, 144-153. [CrossRef]

51. Komeda, S.; Casini, A. Next-Generation Anticancer Metallodrugs. Curr. Top. Med. Chem. 2012, 12, 219-235. [CrossRef]

52. Frezza, M.; Hindo, S.; Chen, D.; Davenport, A.; Schmitt, S.; Tomco, D.; Dou, Q.P. Novel Metals and Metal Complexes as Platforms for Cancer Therapy. Curr. Pharm. Des. 2010, 16, 1813-1825. [CrossRef] 
53. Arnesano, F.; Natile, G. Mechanistic insight into the cellular uptake and processing of cisplatin 30 years after its approval by FDA. Coord. Chem. Rev. 2009, 253, 2070-2081. [CrossRef]

54. Wheate, N.J.; Walker, S.; Craig, G.E.; Oun, R. The status of platinum anticancer drugs in the clinic and in clinical trials. Dalton Trans. 2010, 39, 8113-8127. [CrossRef] [PubMed]

55. Kelland, L. The resurgence of platinum-based cancer chemotherapy. Nat. Rev. Cancer 2007, 7, 573-584. [CrossRef] [PubMed]

56. Shen, D.-W.; Pouliot, L.M.; Hall, M.D.; Gottesman, M.M. Cisplatin Resistance: A Cellular Self-Defense Mechanism Resulting from Multiple Epigenetic and Genetic Changes. Pharmacol. Rev. 2012, 64, 706-721. [CrossRef]

57. Timerbaev, A.R.; Hartinger, C.G.; Aleksenko, S.S.; Keppler, B.K. Interactions of Antitumor Metallodrugs with Serum Proteins: Advances in Characterization Using Modern Analytical Methodology. Chem. Rev. 2006, 106, 2224-2248. [CrossRef]

58. De Araújo, R.F.; de Araújo, A.A.; Pessoa, J.B.; Neto, F.P.F.; da Silva, G.R.; Oliveira, A.L.C.L.; Carvalho, T.G.; Silva, H.F.O.; Eugênio, M.; Sant'Anna, C.; et al. Anti-inflammatory, analgesic and anti-tumor properties of gold nanoparticles. Pharmacol. Rep. 2017, 69, 119-129. [CrossRef]

59. Aminabad, N.S.; Farshbaf, M.; Akbarzadeh, A. Recent Advances of Gold Nanoparticles in Biomedical Applications: State of the Art. Cell Biochem. Biophys. 2018, 77, 123-137. [CrossRef]

60. Upreti, M.; Jyoti, A.; Sethi, P. Tumor microenvironment and nanotherapeutics. Transl. Cancer Res. 2013, 2, 309-319. [CrossRef]

61. Kalaydina, R.-V.; Bajwa, K.; Qorri, B.; DeCarlo, A.; Szewczuk, M.R. Recent advances in "smart" delivery systems for extended drug release in cancer therapy. Int. J. Nanomed. 2018, ume 13, 4727-4745. [CrossRef]

62. Pérez-Herrero, E.; Fernández-Medarde, A. Advanced targeted therapies in cancer: Drug nanocarriers, the future of chemotherapy. Eur. J. Pharm. Biopharm. 2015, 93, 52-79. [CrossRef]

63. Blanco, E.; Shen, H.; Ferrari, M. Principles of nanoparticle design for overcoming biological barriers to drug delivery. Nat. Biotechnol. 2015, 33, 941-951. [CrossRef] [PubMed]

64. Zaki, A.A.; Hui, J.Z.; Higbee, E.; Tsourkas, A. Biodistribution, Clearance, and Toxicology of Polymeric Micelles Loaded with 0.9 or $5 \mathrm{Nm}$ Gold Nanoparticles. J. Biomed. Nanotechnol. 2015, 11, 1836-1846. [CrossRef]

65. Balasubramanian, S.K.; Jittiwat, J.; Manikandan, J.; Ong, C.N.; Yu, L.; Ong, W.-Y. Biodistribution of gold nanoparticles and gene expression changes in the liver and spleen after intravenous administration in rats. Biomaterials 2010, 31, 2034-2042. [CrossRef] [PubMed]

66. Bednarski, M.; Dudek, M.; Knutelska, J.; Nowiński, L.; Sapa, J.; Zygmunt, M.; Nowak, G.; Luty-Błocho, M.; Wojnicki, M.; Fitzner K. The Influence of the Route of Administration of Gold Nanoparticles on Their Tissue Distribution and Basic Bio-chemical Parameters: In Vivo Studies. Pharmacol. Rep. 2015, 67, 405-409. [CrossRef] [PubMed]

67. Wojnicki, M.; Luty-Błocho, M.; Bednarski, M.; Dudek, M.; Knutelska, J.; Sapa, J.; Zygmunt, M.; Nowak, G.; Fitzner, K. Tissue distribution of gold nanoparticles after single intravenous administration in mice. Pharmacol. Rep. 2013, 65, 1033-1038. [CrossRef]

68. Nobili, S.; Mini, E.; Landini, I.; Gabbiani, C.; Casini, A.; Messori, L. Gold compounds as anticancer agents: Chemistry, cellular pharmacology, and preclinical studies. Med. Res. Rev. 2009, 30, 550-580. [CrossRef] [PubMed]

69. Bertrand, B.; Williams, M.R.M.; Bochmann, M. Gold(III) Complexes for Antitumor Applications: An Overview. Chem.-A Eur. J. 2018, 24, 11840-11851. [CrossRef]

70. Casini, A.; Sun, R.W.-Y.; Ott, I. Medicinal Chemistry of Gold Anticancer Metallodrugs. Met. Ions Life Sci. 2018, 18. [CrossRef]

71. Jurgens, S.; Kuhn, F.E.; Casini, A. Cyclometalated Complexes of Platinum and Gold with Biological Properties: State-of-the-Art and Future Perspectives. Curr. Med. Chem. 2018, 25, 437-461. [CrossRef]

72. Lazarevic, T.; Rilak, A.; Bugarčić, Ž.D. Platinum, palladium, gold and ruthenium complexes as anticancer agents: Current clinical uses, cytotoxicity studies and future perspectives. Eur. J. Med. Chem. 2017, 142, 8-31. [CrossRef]

73. Parveen, S.; Arjmand, F.; Tabassum, S. Development and future prospects of selective organometallic compounds as anticancer drug candidates exhibiting novel modes of action. Eur. J. Med. Chem. 2019, 175, 269-286. [CrossRef]

74. Porchia, M.; Pellei, M.; Marinelli, M.; Tisato, F.; Del Bello, F.; Santini, C. New insights in Au-NHCs complexes as anticancer agents. Eur. J. Med. Chem. 2018, 146, 709-746. [CrossRef]

75. Yeo, C.; Ooi, K.; Tiekink, E. Gold-Based Medicine: A Paradigm Shift in Anti-Cancer Therapy? Molecules 2018, 23, 1410. [CrossRef]

76. Zou, T.; Lum, C.T.; Lok, C.-N.; Zhang, J.-J.; Che, C.-M. Chemical biology of anticancer gold(iii) and gold(i) complexes. Chem. Soc. Rev. 2015, 44, 8786-8801. [CrossRef]

77. Ott, I. On the medicinal chemistry of gold complexes as anticancer drugs. Coord. Chem. Rev. 2009, 253, 1670-1681. [CrossRef]

78. Casini, A. Exploring the mechanisms of metalbased pharmacological agents via an integrated approach. J. Inorg. Biochem. 2012, 109, 97-106. [CrossRef]

79. Chen, X.; Yang, Q.; Xiao, L.; Tang, D.; Dou, Q.P.; Liu, J. Metal-Based Proteasomal Deubiquitinase Inhibitors as Potential An-ticancer Agents. Cancer Metastasis Rev. 2017, 36, 655-668. [CrossRef] [PubMed]

80. Casini, A.; Messori, L. Molecular Mechanisms and Proposed Targets for Selected Anticancer Gold Compounds. Curr. Top. Med. Chem. 2011, 11, 2647-2660. [CrossRef] [PubMed]

81. Powis, G.; Montfort, W.R. Properties and Biological Activities of Thioredoxins. Annu. Rev. Pharmacol. Toxicol. 2001, 41, 261-295. [CrossRef] [PubMed]

82. Raffel, J.; Bhattacharyya, A.K.; Gallegos, A.; Cui, H.; Einspahr, J.G.; Alberts, D.S.; Powis, G. Increased expression of thioredoxin-1 in human colorectal cancer is associated with decreased patient survival. J. Lab. Clin. Med. 2003, 142, 46-51. [CrossRef] 
83. Arsenijevic, M.; Milovanovic, M.; Volarevic, V.; Djekovic, A.; Kanjevac, T.; Arsenijevic, N.; Dukic, S.; Bugarcic, Z.D. Cytotoxicity of gold(III) Complexes on A549 Human Lung Carcinoma Epithelial Cell Line. Med. Chem. 2012, 8, 2-8. [CrossRef] [PubMed]

84. Calamai, P.; Carotti, S.; Guerri, A.; Mazzei, T.; Messori, L.; Mini, E.; Orioli, P.; Speroni, G.P. Cytotoxic effects of gold(III) complexes on established human tumor cell lines sensitive and resistant to cisplatin. Anti-Cancer Drug Des. 1998, 13, 67-80.

85. Wilson, C.R.; Fagenson, A.M.; Ruangpradit, W.; Muller, M.T.; Munro, O.Q. Gold (III) Complexes of Pyridyl-and Iso-quinolylamido Ligands: Structural, Spectroscopic, and Biological Studies of a New Class of Dual Topoisomerase I and II In-hibitors. Inorg. Chem. 2013, 52, 7889-7906. [CrossRef]

86. Shi, P.; Jiang, Q.; Lin, J.; Zhao, Y.; Lin, L.; Guo, Z. Gold(III) compounds of 1,4,7-triazacyclononane showing high cytotoxicity against A-549 and HCT-116 tumor cell lines. J. Inorg. Biochem. 2006, 100, 939-945. [CrossRef]

87. Dandash, F.; Léger, D.Y.; Fidanzi-Dugas, C.; Nasri, S.; Brégier, F.; Granet, R.; Karam, W.; Diab-Assaf, M.; Sol, V.; Liagre, B. In vitro anticancer activity of new gold(III) porphyrin complexes in colon cancer cells. J. Inorg. Biochem. 2017, 177, 27-38. [CrossRef]

88. Quero, J.; Cabello, S.; Fuertes, T.; Mármol, I.; Laplaza, R.; Polo, V.; Gimeno, M.C.; Rodriguez-Yoldi, M.J.; Cerrada, E. Proteasome versus Thioredoxin Reductase Competition as Possible Biological Targets in Antitumor Mixed Thiolate-Dithiocarbamate Gold(III) Complexes. Inorg. Chem. 2018, 57, 10832-10845. [CrossRef]

89. Bertrand, B.; Spreckelmeyer, S.; Bodio, E.; Cocco, F.; Picquet, M.; Richard, P.; Le Gendre, P.; Orvig, C.; Cinellu, M.A.; Casini, A. Exploring the potential of gold(iii) cyclometallated compounds as cytotoxic agents: Variations on the $\mathrm{C}^{\wedge} \mathrm{N}$ theme. Dalton Trans. Camb. Engl. 2015, 44, 11911-11918. [CrossRef]

90. Erdogan, E.; Lamark, T.; Stallings-Mann, M.; Jamieson, L.; Pellechia, M.; Thompson, E.A.; Johansen, T.; Fields, A.P. Aurothiomalate Inhibits Transformed Growth by Targeting the PB1 Domain of Protein Kinase Cı. J. Biol. Chem. 2006, 281, 28450-28459. [CrossRef] [PubMed]

91. Islam, S.M.A.; Patel, R.; Acevedo-Duncan, M. Protein Kinase C- $\zeta$ stimulates colorectal cancer cell carcinogenesis via PKC$\zeta /$ Rac1/Pak1/ß-Catenin signaling cascade. Biochim. Biophys. Acta Mol. Cell Res. 2018, 1865, 650-664. [CrossRef]

92. Wang, Y.; He, Q.-Y.; Che, C.M.; Tsao, S.W.; Sun, R.W.-Y.; Chiu, J.-F. Modulation of gold(III) porphyrin 1a-induced apoptosis by mitogen-activated protein kinase signaling pathways. Biochem. Pharmacol. 2008, 75, 1282-1291. [CrossRef] [PubMed]

93. Tong, K.-C.; Lok, C.-N.; Wan, P.-K.; Hu, D.; Fung, Y.M.E.; Chang, X.-Y.; Huang, S.; Jiang, H.; Che, C.-M. An anticancer gold(III)activated porphyrin scaffold that covalently modifies protein cysteine thiols. Proc. Natl. Acad. Sci. USA 2020, 117, 1321-1329. [CrossRef] [PubMed]

94. Mirabelli, C.K.; Sung, C.-M.; Zimmerman, J.P.; Hill, D.T.; Mong, S.; Crooke, S.T. Interactions of gold coordination complexes with DNA. Biochem. Pharmacol. 1986, 35, 1427-1433. [CrossRef]

95. Mirabelli, C.K.; Zimmerman, J.P.; Bartus, H.R.; Chiu-Mei, S.; Crooke, S.T. Inter-strand cross-links and single-strand breaks produced by gold(I) and gold(III) coordination complexes. Biochem. Pharmacol. 1986, 35, 1435-1443. [CrossRef]

96. Bindoli, A.; Rigobello, M.P.; Scutari, G.; Gabbiani, C.; Casini, A.; Messori, L. Thioredoxin reductase: A target for gold compounds acting as potential anticancer drugs. Coord. Chem. Rev. 2009, 253, 1692-1707. [CrossRef]

97. Nardon, C.; Boscutti, G.; Fregona, D. Beyond platinums: Gold complexes as anticancer agents. Anticancer. Res. 2014, 34, 487-492.

98. Buckley, R.G.; Elsome, A.M.; Fricker, S.P.; Henderson, G.R.; Theobald, B.R.C.; Parish, R.V.; Howe, A.B.P.; Kelland, L.R. Antitumor Properties of Some 2-[(Dimethylamino)methyl]phenylgold(III) Complexes. J. Med. Chem. 1996, 39, 5208-5214. [CrossRef]

99. Parish, R.V.; Howe, B.P.; Wright, J.P.; Mack, J.; Pritchard, R.G.; Buckley, R.G.; Elsome, A.M.; Fricker, S.P. Chemical and Bio-logical Studies of Dichloro (2-((Dimethylamino) Methyl) Phenyl) Gold (III). Inorg. Chem. 1996, 35, 1659-1666. [CrossRef]

100. Zhu, Y.; Cameron, B.R.; Mosi, R.; Anastassov, V.; Cox, J.; Qin, L.; Santucci, Z.; Metz, M.; Skerlj, R.T.; Fricker, S.P. Inhibition of the Cathepsin Cysteine Proteases B and K by Square-Planar Cycloaurated Gold (III) Compounds and Investigation of Their Anti-Cancer Activity. J. Inorg. Biochem. 2011, 105, 754-762. [CrossRef]

101. Notash, B.; Amani, V.; Safari, N.; Ostad, S.N.; Abedi, A.; Dehnavi, M.Z. The Influence of Steric Effects on Intramolecular Secondary Bonding Interactions; Cytotoxicity in Gold (III) Bithiazole Complexes. Dalton Trans. 2013, 42, 6852-6858. [CrossRef]

102. Carrasco, J.; Criado, J.J.; Macias, R.; Manzano, J.L.; Marin, J.; Medarde, M.; Rodríguez, E. Structural characterization and cytostatic activity of chlorobischolylglycinatogold(III). J. Inorg. Biochem. 2001, 84, 287-292. [CrossRef]

103. Messori, L.; Marcon, G.; Cinellu, M.A.; Coronnello, M.; Mini, E.; Gabbiani, O.; Orioli, P. Solution chemistry and cytotoxic properties of novel organogold(III) compounds. Bioorganic Med. Chem. 2004, 12, 6039-6043. [CrossRef]

104. Massai, L.; Cirri, D.; Michelucci, E.; Bartoli, G.; Guerri, A.; Cinellu, M.A.; Cocco, F.; Gabbiani, C.; Messori, L. Organogold(III) compounds as experimental anticancer agents: Chemical and biological profiles. BioMetals 2016, 29, 863-872. [CrossRef] [PubMed]

105. Ronconi, L.; Giovagnini, L.; Marzano, C.; Bettìo, F.; Graziani, R.; Pilloni, G.; Fregona, D. Gold Dithiocarbamate Derivatives as Potential Antineoplastic Agents: Design, Spectroscopic Properties, and in Vitro Antitumor Activity. Inorg. Chem. 2005, 44, 1867-1881. [CrossRef]

106. Ronconi, L.; Fregona, D. The Midas touch in cancer chemotherapy: From platinum- to gold-dithiocarbamato complexes. Dalton Trans. 2009, 10670-10680. [CrossRef] [PubMed]

107. Nardon, C.; Chiara, F.; Brustolin, L.; Gambalunga, A.; Ciscato, F.; Rasola, A.; Trevisan, A.; Fregona, D. Gold(III)pyrrolidinedithiocarbamato Derivatives as Antineoplastic Agents. ChemistryOpen 2015, 4, 183-191. [CrossRef]

108. Casini, A.; Kelter, G.; Gabbiani, C.; Cinellu, M.A.; Minghetti, G.; Fregona, D.; Fiebig, H.-H.; Messori, L. Chemistry, antiproliferative properties, tumor selectivity, and molecular mechanisms of novel gold(III) compounds for cancer treatment: A systematic study. JBIC J. Biol. Inorg. Chem. 2009, 14, 1139-1149. [CrossRef] [PubMed] 
109. Czerwińska, K.; Golec, M.; Skonieczna, M.; Palion-Gazda, J.; Zygadło, D.; Szlapa-Kula, A.; Krompiec, S.; Machura, B.; Szurko, A. Cytotoxic gold(iii) complexes incorporating a 2,2': $: 6^{\prime}, 2^{\prime \prime}$-terpyridine ligand framework-The impact of the substituent in the $4^{\prime}$-position of a terpy ring. Dalton Trans. 2017, 46, 3381-3392. [CrossRef] [PubMed]

110. Casado-Sánchez, A.; Martín-Santos, C.; Padrón, J.M.; Mas-Ballesté, R.; Navarro-Ranninger, C.; Alemán, J.; Cabrera, S. Effect of Electronic and Steric Properties of 8-Substituted Quinolines in Gold (III) Complexes: Synthesis, Electrochemistry, Stability, Interactions and Antiproliferative Studies. J. Inorg. Biochem. 2017, 174, 111-118. [CrossRef] [PubMed]

111. Pettenuzzo, N.; Brustolin, L.; Coltri, E.; Gambalunga, A.; Chiara, F.; Trevisan, A.; Biondi, B.; Nardon, C.; Fregona, D. CuIIand AuIIIComplexes with Glycoconjugated Dithiocarbamato Ligands for Potential Applications in Targeted Chemotherapy. ChemMedChem 2019, 14, 1162-1172. [CrossRef] [PubMed]

112. Sun, R.W.-Y.; Li, C.K.-L.; Ma, D.-L.; Yan, J.J.; Lok, C.-N.; Leung, C.-H.; Zhu, N.; Che, C.-M. Stable Anticancer Gold(III)-Porphyrin Complexes: Effects of Porphyrin Structure. Chem.-A Eur. J. 2010, 16, 3097-3113. [CrossRef]

113. Che, C.-M.; Sun, R.W.-Y.; Yu, W.-Y.; Ko, C.-B.; Zhu, N.; Sun, H. Gold(iii) porphyrins as a new class of anticancer drugs: Cytotoxicity, DNA binding and induction of apoptosis in human cervix epitheloid cancer cellsElectronic supplementary information (ESI) available: Further experimental and crystallographic details. Chem. Commun. 2003, 1718-1719. [CrossRef]

114. Tu, S.; Sun, R.W.-Y.; Lin, M.C.M.; Cui, J.T.; Zou, B.; Gu, Q.; Kung, H.-F.; Che, C.M.; Wong, B.C.Y. Gold (III) porphyrin complexes induce apoptosis and cell cycle arrest and inhibit tumor growth in colon cancer. Cancer 2009, 115, 4459-4469. [CrossRef]

115. Altaf, M.; Ahmad, S.; Kawde, A.-N.; Baig, N.; Alawad, A.; Altuwaijri, S.; Stoeckli-Evans, H.; Isab, A.A. Synthesis, Structural Characterization, Electrochemical Behavior and Anticancer Activity of Gold (Iii) Complexes of Meso-1, 2-Di (1-Naphthyl)-1, 2-Diaminoethane and Tetraphenylporphyrin. New J. Chem. 2016, 40, 8288-8295. [CrossRef]

116. Lemke, J.; Pinto, A.; Niehoff, P.; Vasylyeva, V.; Metzler-Nolte, N. Synthesis, structural characterisation and anti-proliferative activity of NHC gold amino acid and peptide conjugates. Dalton Trans. 2009, 7063-7070. [CrossRef]

117. Dinda, J.; Samanta, T.; Nandy, A.; Saha, K.D.; Seth, S.K.; Chattopadhyay, S.K.; Bielawski, C.W. N-Heterocyclic Carbene Sup-ported $\mathrm{Au}(\mathrm{I})$ and $\mathrm{Au}(\mathrm{III})$ Complexes: A Comparison of Cytotoxicities. New J. Chem. 2014, 38, 1218-1224. [CrossRef]

118. Rana, B.K.; Nandy, A.; Bertolasi, V.; Bielawski, C.W.; Saha, K.D.; Dinda, J. Novel Gold(I)- and Gold(III)-N-Heterocyclic Carbene Complexes: Synthesis and Evaluation of Their Anticancer Properties. Organometallics 2014, 33, 2544-2548. [CrossRef]

119. Samanta, T.; Munda, R.N.; Roymahapatra, G.; Nandy, A.; Saha, K.D.; Al-Deyab, S.S.; Dinda, J. Silver (I), Gold (I) and Gold (III)-N-Heterocyclic Carbene Complexes of Naphthyl Substituted Annelated Ligand: Synthesis, Structure and Cytotoxicity. J. Organomet. Chem. 2015, 791, 183-191. [CrossRef]

120. Jhulki, L.; Dutta, P.; Santra, M.K.; Cardoso, M.H.; Oshiro, K.G.; Franco, O.L.; Bertolasi, V.; Isab, A.A.; Bielawski, C.W.; Dinda, J. Synthesis and Cytotoxic Characteristics Displayed by a Series of Ag(i)-, Au(i)-and Au(Iii)-Complexes Supported by a Common N-Heterocyclic Carbene. New J. Chem. 2018, 42, 13948-13956. [CrossRef]

121. Liu, W.; Bensdorf, K.; Proetto, M.; Abram, U.; Hagenbach, A.; Gust, R. NHC Gold Halide Complexes Derived from 4,5Diarylimidazoles: Synthesis, Structural Analysis, and Pharmacological Investigations as Potential Antitumor Agents. J. Med. Chem. 2011, 54, 8605-8615. [CrossRef] [PubMed]

122. Liu, W.; Bensdorf, K.; Proetto, M.; Hagenbach, A.; Abram, U.; Gust, R. Synthesis, Characterization, and in Vitro Studies of Bis [1,3-Diethyl-4, 5-Diarylimidazol-2-Ylidene] Gold (I/III) Complexes. J. Med. Chem. 2012, 55, 3713-3724. [CrossRef]

123. Fung, S.K.; Zou, T.; Cao, B.; Lee, P.-Y.; Fung, Y.M.E.; Hu, D.; Lok, C.-N.; Che, C.-M. Cyclometalated Gold(III) Complexes Containing N-Heterocyclic Carbene Ligands Engage Multiple Anti-Cancer Molecular Targets. Angew. Chem. Int. Ed. 2017, 56, 3892-3896. [CrossRef]

124. Krajewska, J.; Włodarczyk, J.; Jacenik, D.; Kordek, R.; Taciak, P.; Szczepaniak, R.; Fichna, J. New Class of Anti-Inflammatory Therapeutics Based on Gold (III) Complexes in Intestinal Inflammation-Proof of Concept Based on In Vitro and In Vivo Studies. Int. J. Mol. Sci. 2021, 22, 3121. [CrossRef]

125. Lipiec, S.; Szymański, P.; Gurba, A.; Szeleszczuk, Ł.; Taciak, P.; Fichna, J.; Młynarczuk-Biały, I. Innovative Gold Complexes with CN Group as Anticancer Agents-Possible Mechanisms of Action. In Advances in Biomedical Research-Cancer and Miscellaneous; Młynarczuk-Biały, I., Biały, Ł., Eds.; Wydawnictwo Naukowe Tygiel Sp. z o. o.: Lubin, Poland, 2021; pp. 9-22. ISBN 978-83-6710412-8. Available online: https:/ / bc.wydawnictwo-tygiel.pl/publikacja/AA60CB34-1A06-4ECD-748B-83D6A9A5B19C (accessed on 15 December 2021).

126. Engman, L.; McNaughton, M.; Gajewska, M.; Kumar, S.; Birmingham, A.; Powis, G. Thioredoxin reductase and cancer cell growth inhibition by organogold(III) compounds. Anti-Cancer Drugs 2006, 17, 539-544. [CrossRef] [PubMed]

127. Karaaslan, M.G.; Aktaş, A.; Gürses, C.; Gök, Y.; Ateş, B. Chemistry, structure, and biological roles of Au-NHC complexes as TrxR inhibitors. Bioorganic Chem. 2019, 95, 103552. [CrossRef] [PubMed]

128. Massai, L.; Grguric-Sipka, S.; Liu, W.; Bertrand, B.; Pratesi, A. Editorial: The Golden Future in Medicinal Chemistry: Perspectives and Resources from Old and New Gold-Based Drug Candidates. Front. Chem. 2021, 9. [CrossRef] [PubMed] 